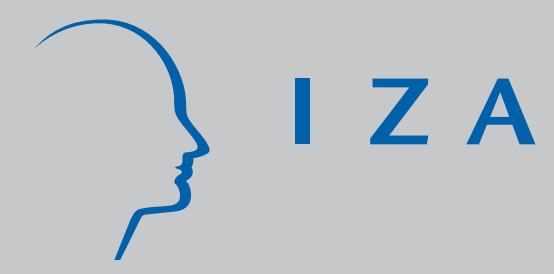

IZADP No. 1477

\title{
'Atypical Work' and Compensation
}

J ohn T. Addison

Christopher J. Surfield

J anuary 2005 


\title{
'Atypical Work' and Compensation
}

\author{
John T. Addison \\ University of South Carolina, \\ University of Coimbra/GEMF and IZA Bonn \\ Christopher J. Surfield \\ Lander University
}

\section{Discussion Paper No. 1477 \\ January 2005}

\author{
IZA \\ P.O. Box 7240 \\ 53072 Bonn \\ Germany \\ Phone: +49-228-3894-0 \\ Fax: +49-228-3894-180 \\ Email: iza@iza.org
}

\begin{abstract}
Any opinions expressed here are those of the author(s) and not those of the institute. Research disseminated by IZA may include views on policy, but the institute itself takes no institutional policy positions.
\end{abstract}

The Institute for the Study of Labor (IZA) in Bonn is a local and virtual international research center and a place of communication between science, politics and business. IZA is an independent nonprofit company supported by Deutsche Post World Net. The center is associated with the University of Bonn and offers a stimulating research environment through its research networks, research support, and visitors and doctoral programs. IZA engages in (i) original and internationally competitive research in all fields of labor economics, (ii) development of policy concepts, and (iii) dissemination of research results and concepts to the interested public.

IZA Discussion Papers often represent preliminary work and are circulated to encourage discussion. Citation of such a paper should account for its provisional character. A revised version may be available directly from the author. 


\section{ABSTRACT}

\section{'Atypical Work' and Compensation}

Atypical work, or alternative work arrangements in U.S. parlance, has long been criticized for providing poorly-compensated employment. Although one group of atypical workers (contractors) seems to enjoy a wage premium, our cross-section results from the CPS and NLSY for the better-known category of temporary workers point to a negative wage differential of some 7-12 percent. It emerges that much of the latter disparity stems from unobserved worker heterogeneity (accounting for which supports a wage advantage for contracting work). Turning to fringes, the appearance in cross section of a potentially large deficit in atypical worker health benefits is again reduced after accounting for permanent unobserved individual heterogeneity. But on this occasion the reduction is very modest. Further, there is now some indication that the wage advantage of contract workers partly compensates for their reduced access to such benefits.

JEL Classification: J31, J33, J4

Keywords: atypical/contingent work, alternative work arrangements, wage differentials, employer-related health insurance

Corresponding author:

John T. Addison

Department of Economics

Moore School of Business

University of South Carolina

1705 College Street

Columbia, SC 29208

USA.

Email: ecceaddi@moore.sc.edu 


\section{Introduction}

The frequency of alternative work arrangements (AWAs) such as consulting, contract, and temporary work - more familiarly referred to as "atypical work" in Europe - has steadily increased in recent decades (e.g. Segal and Sullivan, 1997). Research has tended to focus on the nature and extent of such arrangements and their impact on a worker's employment history (e.g. Addison and Surfield, 2005). The compensation packages that are associated with these AWAs have been accorded less attention in the empirical literature. What research there is, however, paints a rather bleak picture: compared with open-ended (regular) employment, alternative work arrangements often appear to offer a markedly inferior compensation package and seem to merit the atypical worker tag.

There are various reasons why a negative differential might attach to atypical work. Under compensating differential theory, workers receive wage discounts or premiums that reflect differences in the desirability of the various employment options. If the aggregate demand by firms for atypical workers is smaller than the number of individuals seeking such employment arrangements, then the lower earnings pointed to in the literature might indicate a true differential. In the case that the alternative employment market is substantially different from that of open-ended employment, different wage equilibria may be established. Firms may contract out wage and benefit costs for non-core workers, and they may deploy outside contractors to buffer the regular workforce from fluctuations in demand. For both reasons, wage inequality might increase over time with the growth in atypical work. ${ }^{1}$

A second reason why atypical work might attract lower wages stems from human capital considerations. Workers may select AWAs as a means to acquire additional training or labor market experience. For example, Autor (2001) reports that temporary agencies offering at least rudimentary computer training paid lower wages than their counterparts that did not to offer similar opportunities. Alternatively, workers may use these types of work arrangements to babysit their existing stocks of human capital, or otherwise prevent deterioration in their future labor market prospects by reason of stigmatization from exposure to prolonged unemployment. For example, as noted by Farber (1999), (displaced) unemployed workers are initially - although not subsequently - more likely to be observed as holding AWA employment. ${ }^{2}$ In short, in exchange for enhanced skill-sets or future employment in regular employment, workers may accept reduced compensation packages. 
A third possibility is that worker ability and employment in an AWA are negatively correlated. In this case, negative compensation differentials are attributable not to the employment arrangement but to the (lesser) ability of the typical incumbent. In short, faulty inferences as to the extent of wage disparities may be made if low-ability workers sort themselves into AWA employment. We will focus on this possibility here, examining the association between compensation and employment arrangement in a framework that controls for unobserved worker heterogeneity. The two most important components of the compensation package are considered: wages (72.4 percent of labor costs) and (access to) employer-related health insurance (6.5 percent) (United States Department of Labor, 2002).

The plan of the paper is as follows. A thumbnail sketch of the existing empirical literature is first provided. Next, the empirical model is reviewed, followed by a description of the two datasets used in this inquiry (the Current Population Survey and the National Longitudinal Survey of Youth, 1979 Cohort). Our detailed findings are then presented. A brief summary concludes.

\section{Existing Research}

The paucity of research into AWAs is attributable to two causes. First, it was not until the 1980s that structural developments in the labor market - such as the attenuation of the common law atwill principle (see Autor, 2003) - favored the growth of atypical work. Second, there was understandably little quality data on work arrangements that had up to that point played a marginal employment role. More recently, analysts have been able to make progress in identifying the impact of AWAs on earnings, inter al., through the identification of workers engaged in the Temporary Help Services (THS) industry. And, since 1995, investigation of other types of atypical work has been facilitated by the publication of a Contingent and Alternative Employment Arrangement Supplement (CAEAS) to the Current Population Survey (CPS). This new supplement was administered biennially with the February CPS (in odd years) until it was discontinued after February 2001.

(Table 1 near here)

A chronological review of the U.S. literature on atypical work and its remuneration is provided in Table 1. As can be seen, many of the studies have a narrow reach, having a basis in cross tabulations of AWA employment and key compensation measures such as hourly earnings 
and group health insurance coverage. One representative such study is Cohany (1998), who reviews data from the second CAEAS (row 6). Vis-à-vis the first CAEAS, little change in the characteristics of atypical workers is reported, and again a comparison of the median weekly earnings of atypical workers and those in open-ended employment shows that agency temporaries and oncall workers fare particularly poorly. For example, the median weekly earnings of agency temporary workers are only two-thirds of those of regular workers. That said, and again consistent with findings from the earlier CAEAS, those individuals identified as independent contractors and contract workers enjoy a wage premium - of fifteen and twenty-one percent, respectively.

Cohany's cross tabulations also uncover a sharp deficit in atypical worker fringes. Health insurance coverage rates range from a low of seven percent (agency temporary workers) to a high of fifty percent (contract workers). And in terms of eligibility to participate in employer pension plans, temporaries were again at the low end (eleven percent) and contractors at the high end (forty-six percent) of the scale. By contrast, more than sixty percent of regular workers had employer-related health insurance coverage, ${ }^{3}$ and more than fifty percent were eligible for a pension plan.

Differences in the compensation packages associated with the various employment arrangements may of course reflect differences in worker characteristics. Thus, for example, Cohany reports that atypical workers are younger, have lower educational attainments, and are more concentrated in the lower-paid industries and occupations than are regular workers. Segal and Sullivan $(1997,1998)$ were among the first to present a cet. par. earnings analysis (rows 4 and 7). In their later study, they exploit administrative data rather than the CAEAS, extracting a ten-year sample panel from the 1984-94 quarterly records contained in the Washington State Unemployment Insurance system and identifying temporary employees through their industry affiliation. ${ }^{4}$ In addition to their cross-section results, and to compensate for their lack of demographic and occupation controls, Segal and Sullivan also provide fixed effect regression estimates. Accounting for permanent unobserved individual heterogeneity reduces the earnings deficit of temporary workers to between ten and fifteen percent.

Finally, in a labor market analysis of single-parent female welfare recipients initially obtaining atypical work in the temporary help service sector versus other industries, Heinrich, Mueser, and Troske (2002) report that this choice does not prejudice their future earnings 
development or continued employment - or for that matter welfare recidivism. Welfare recipients beginning work in this sector do earn substantially less than their counterparts in other sectors, but this difference does not seem to be the result of unmeasured characteristics. Moreover, the low earnings are not permanent: after two years the differences between those initially in atypical work are virtually the same as their counterparts who had jobs in other industries. This faster earnings growth is shown to be partly the result of atypical workers moving to other higher-paying industries. And there is no difference in the proportions of workers who do not have a job one year later across industries, including temporary help. The bottom line from this study is that welfare recipients obtain opportunities for future advancement by working in the temporary help service sector.

In the present study we will attempt to see whether these more optimistic results obtain using a more representative sample of workers, a wider range of controls - including job matching as well as industry, occupational, and human capital measures - and for a fuller group of alternative work arrangements.

\section{The Empirical Models}

To assess the impact that atypical work has on the compensation package, we conduct separate analyses of (hourly) earnings and (access to) employer-provided health benefits.

\section{Wage Determination}

Consider the underlying wage determination model that includes worker ability

$$
E\left(w_{i, t} \mid x_{i, t}, A W A_{i, t}, c_{i}\right)=\beta^{\prime} x_{i, t}+\delta A W A_{i, t}+c_{i}, \quad \mathrm{t}=1,2, \ldots \mathrm{T}
$$

where $w_{i, t}$ is the $(\log )$ wage earned by worker $i$ at time $t, x_{i, t}$ are the corresponding observed worker characteristics, $A W A_{i, t}$ is a dummy variable equal to one if a worker $i$ is engaged in an AWA at time $t$ (zero otherwise), and $c_{i}$ is worker ability. The parameter $\delta$ is the wage differential that is associated with employment in an AWA.

When equation ( 1 ) is estimated by OLS, we have

$$
w_{i, t}=\beta^{\prime} x_{i, t}+\delta A W A_{i, t}+c_{i}+u_{i, t} .
$$

Absent controls for worker ability, OLS will estimate

$$
w_{i, t}=\beta^{\prime} x_{i, t}+\delta A W A_{i, t}+v_{i, t},
$$


where $v_{i, t}=\left(c_{i}+u_{i, t}\right)$. Equation (3) will still provide unbiased estimates of $\delta$ provided $E\left[v_{i, t} \mid x_{i, t}\right]=0$. If (as we would hypothesize) ability and employment arrangements are negatively correlated, however, the estimate of the wage differential will be biased downward.

We can remove worker ability from the model using a fixed effect specification that will also be estimated alongside equation (3). The fixed effect specification allows for not only individual-specific intercepts but also year-specific intercepts, as follows

$$
w_{i, t}=\alpha_{t}+\phi_{i}+\beta^{\prime} x_{i, t}+\delta A W A_{i, t}+u_{i, t},
$$

where $\alpha_{t}$ captures the impact if any that time has on worker earnings and where the individualspecific intercept $\phi_{i}$ which controls for any time-invariant unobserved worker characteristics such as ability. Any elements of $x_{i, t}$ that are unchanging over time are omitted from (4).

\section{Employer-Related Health Insurance}

In analyzing the question of access to group health insurance (HI), the correlation between ability and employment in an AWA may again bias the estimate of $\delta$. Since the dependent variable is now dichotomous, we use the logit model

$$
H I_{i, t}^{*}=\beta^{\prime} x_{i, t}+\delta A W A_{i, t}+c_{i}+u_{i, t},
$$

where $H I$ is observed to be one if $H I^{*}>0$, zero otherwise. Ability is again represented by $c_{i}$.

The standard logit model is based on the assumption that the probability of having access to health insurance in the presence of unobserved heterogeneity is

$$
\operatorname{Pr}\left(H I_{i, t}=1\right)=\frac{e^{\beta^{\prime} x_{i, t}+\delta A W A_{i, t}}}{1+e^{\beta^{\prime} x_{i, t}+\delta A W A_{i, t}}} .
$$

If $c_{i}$ is omitted, the fitted model, will yield an estimate of $\delta$ that may not be the true differential. To handle this concern, we also estimate the following fixed effect logit model

$$
\operatorname{Pr}\left(H I_{i, t}=1\right)=\frac{e^{\phi_{i}+\beta^{\prime} x_{i, t}+\delta A W A_{i, t}}}{1+e^{\phi_{i}+\beta^{\prime} x_{i, t}+\delta A W A_{i, t}}} .
$$

Familiarly, equation (7) differs from (6) in including a worker-specific intercept, allowing for a consistent estimate of the true value of $\delta$. 


\section{The Data}

We use two datasets in searching for robust estimates of the compensation differential attaching to atypical work, namely, the Contingent and Alternative Employment Arrangement Supplement (CAEAS) to the CPS - as well as the parent survey itself - and the National Longitudinal Survey of Youth, 1979 Cohort (NLSY79). The advantage of the former dataset is its size, given the relatively small proportion of workers in certain of the alternative work arrangements. The disadvantage is that there is no overlap of households across the supplements ruling out panel estimation methods. Each attribute is reversed in the case of the latter dataset.

\section{The CAEAS/CPS Wage Data}

Three different samples were extracted from four biennial contingent worker supplements to facilitate the estimation of the standard OLS model and to obtain a base estimate of the differentials attaching to atypical work. ${ }^{5}$ The samples were also pooled to obtain more precise estimates of the wage differentials attaching to the different work arrangements, while accounting for year effects.

The three samples included only those respondents who were employed in the week prior to their February interview. This restriction was imposed because those recorded as unemployed or as non-participants would not report any labor force or wage data. Additionally, workers either reporting or having an imputed hourly wage rate of less than one dollar an hour and more than one hundred dollars an hour were also excluded from the samples. ${ }^{6}$ Further, to limit compounding different supply responses, only those individuals aged twenty-five to sixty-five years at the time of the survey were included. Finally, individuals with incomplete demographic, industrial, and occupational data were excised. All wage data pertain to the individual's primary job.

Workers are segregated into one of seven exclusive work arrangements. The first two groups comprise categories of open-ended employment: regular workers and screened workers. Following the convention established in the literature, workers engaged in alternative work arrangements - atypical workers - were separated into following the five groups of agency temporary workers, direct-hire temporary workers, oncall workers, contract workers, and independent contractors.

Regular workers are those workers who are hired into an open-ended arrangement using standard interviewing methods, rather than being screened via the mechanism of an alternative 
work arrangement. Individuals are deemed to be screened workers if they meet two criteria: they must be engaged in open-ended employment and they must indicate that, immediately prior to being employed by their firm as a regular worker, they had served as an alternative worker. Accordingly, only those workers who had served the firm as both an alternative and open-ended worker without a break in employment were classified as screened. We distinguish between the two types of open-ended employment to allow for the possibility that initially serving an employer as an atypical worker strengthens the bond between employer and employee and thereby influences the wage paid to such workers.

Returning to the five different categories of alternative work arrangements, agency temporary workers are those workers who rely on a third-party, the temporary help service, to secure their job-tasks or receive their paycheck from a temporary help service. ${ }^{7}$ Direct-hire temporary workers are those temporary workers who eschew the assistance of the agency temporary service and arrange to provide their services directly to the paycheck-issuing entity. Furthermore, this category includes those workers who indicate that they are hired directly by the client firm to fill a temporary position, complete a specific project, or substitute for an absent or vacationing employee. Direct-hires are those hired by a firm for only a fixed period of time or into jobs that are seasonal in nature. As a practical matter, we will subsequently aggregate these two temporary categories into a single temporary worker composite. ${ }^{8}$

Oncall workers work for a firm on a per-diem or as-needed basis (day laborers are also folded into this classification). Contract workers differ from independent contractors (see below) in that they, like their agency temporary counterparts, rely on a third-party to provide them with the necessary clients or projects. Following the convention in the literature, we also impose the following restrictions on this category: a contract worker needs to have only one client and usually works at that client's workplace. Finally, those we describe as independent contractors are self-employed consultants and contractors, and are akin to direct-hire temporaries in that they are responsible for the acquisition of clients or projects.

In addition to these base categories we shall also construct some (other) composites, either to test the hypothesis that alternative employment hold uniform implications for a worker's earnings or to facilitate comparison with the NLSY79 (see below). 


\section{The NLSY79 Wage Data}

The National Longitudinal Survey of Youth, 1979 Cohort (NLSY79) is the product of repeated interviews with individuals aged 14-21 years at the time of the initial interview in 1979 (who were therefore just beginning to enter the labor market). ${ }^{9}$

Four different samples were extracted from the NLSY79 for the wage analyses. Three different cross-sections were created to run the standard OLS regressions, covering employees in employment in 1994, 1996, and 1998. The restrictions imposed were, with one exception, the same as those applied for the CAEAS/CPS: we exclude from the NLSY79 samples those workers who failed to accumulate at least nine weeks of tenure with their current employer. The latter restriction was imposed because the dataset does not collect employer-specific information, such as industrial or occupation characteristics, from the respondent unless he or she meets this particular service requirement.

For the fixed effect estimates an unbalanced panel was constructed, covering all three years used for the cross-sectional analysis and applying same restrictions in respect of missing data and the truncation of the wage distribution. This unbalanced panel does not require that workers be recorded as employed for all three years, only for at least two of the three years. The unbalanced panel was constructed to allow for a more precise estimate of $\delta$ by including as many observations on individuals as possible.

Respondents were initially classified into one of five possible job categories that differ somewhat from those constructed from the CAEAS/CPS. The first two categories of regular workers and screened workers, however, are identical to those identified earlier; as before, the distinction is based on the notion that previously screened workers may be in a better job match. Again we consolidate agency temporaries and direct-hire temporaries into a single temporary worker category. We are unable to distinguish between the two types of contract work, so we will here identify contractors/consultants. The remaining category is the catch-all of other work types, of which the most numerous subgroup is self-employment. Other aggregations are discussed below.

\section{Data on Health Insurance}

Although the issues of employee take-up and employer contributions are of central concern, we are here perforce interested in whether or not the employer makes health insurance available to the worker. The CAEAS/CPS provides information on the availability of employer-related health 
insurance but only insofar as the individual has insurance. In circumstances where the employer makes health insurance available but the worker declines it, the CAEAS/CPS will assign a missing value to this individual. Because of this conflation of the issues of availability and takeup, we cannot use the CAEAS/CPS and we will instead rely on the NLSY79, which explicitly asks respondents if this benefit was made available to them, irrespective of whether or not they took up the coverage offered. In investigating the effects of atypical work on insurance availability we will use exactly the same four samples of data as used for our cross-sectional and fixed effect analyses of hourly earnings.

\section{Findings}

Descriptive wage date from the three cross sections of the CAEAS/CPS and the NLSY79 are given in Tables 2 and 3, respectively. Beginning with the CAEAS/CPS, it can be seen that temporaries earn between eighty-four and ninety-eight percent of the wages enjoyed by regular workers. Oncall workers earn slightly more than eighty cents on the regular-employee dollar. By the same token, not all atypical workers have lower earnings. Those engaged in contract work and in the independent contractor category appear to enjoy higher relative earnings. For example, independent contracting employment pays hourly wages that are twenty to fifty percent in excess of those received by regular workers.

(Tables 2 and 3 near here)

The relative earnings differences for temporary workers and contractors/consultants are directionally the same in the NLYS79 data, but systemically sharper. In both datasets, there is some suggestion that screened workers obtain better job matches. Their differentials are almost always positive albeit small: at best they earn eight percent more than their non-screened counterparts in open-ended employment (Table 2), and at worst a little under six percent (Table $3)$.

(Table 4 near here)

Work diaries maintained by the NLSY79 respondents allow us to determine a worker's (cumulative) general labor market experience as well as his/her tenure on the current job. ${ }^{10}$ In addition, we can estimate a standardized measure of the number of jobs held by individuals dividing the reported total number of jobs held by (cumulative) general labor market experience. This standardized jobs variable can also be viewed as an inverse proxy for the attractiveness of 
the worker to an employer. Descriptive information on these variables is provided in Table 4 for the 1994 NLSY79 sample. Not surprisingly workers in alternative work arrangements have substantially less tenure with their employers than do regular workers. In terms of general labor market experience, it would appear that consultants/contractors have been employed slightly longer than regular workers. And, despite their having spent fewer years in employment, temporary workers have held more jobs on average than those engaged in open-ended employment.

\section{(Table 5 near here)}

We next turn to the multivariate cross-section results, beginning with those for the larger CAEAS/CPS sample in Table 5. ${ }^{11}$ Even after controlling for differences in characteristics, those workers engaged in temporary work still appear to earn substantially lower wages vis-à-vis regular work (the omitted category). Temporaries earn eight to eleven percent less than regular workers. F-tests reject the possibility that agency temping has statistically different implications for worker earnings than does direct-hire temping. In the case of oncall work, however, much of the raw differences in hourly wages can be explained by compositional difference. The twenty to thirty percent differential reported in Table 2 now falls to (a statistically significant) six to eight percent.

There is also some attenuation of the simple positive differentials earlier observed for contract workers and especially independent contractors (cf. Table 2). Results for the pooled sample shown in the final column of Table 5 suggest that contract workers have hourly earnings that are ten percent higher than those of regular workers. For independent contractors, the differential is around nineteen percent. Consistent with the findings in Table 2, we detect some modest earnings benefit associated with prior screening in regular employment: for the pooled sample, that differential is a marginally significant two percent.

The notion of a composite atypical work category seems to be inappropriate. This is confirmed by the hypothesis tests located at the foot of the table. Different work arrangements clearly play distinct roles in earnings determination.

(Table 6 near here)

We now turn to the ceteris paribus analysis of the three NLSY79 cross sections in Table 6. In addition to the controls listed in the notes to the table, the regression separately identifies worker experience, tenure, and standardized number of jobs held. ${ }^{12}$ The principal finding is that 
temporary workers earn significantly less than regular workers: the negative differential ranges from seven to eleven percent. Interestingly, the positive differential earlier observed for the two types of contractors in the CAEAS is no longer well determined in the NLSY79 for the composite category of contractors/consultants. But the directional effects of the experience, tenure, and job holding variables are as expected, even if not always well determined.

Finally, a composite atypical worker category was constructed to test the hypothesis that AWAs had a common impact on worker earnings. The F-tests at the base of Table 6 suggest that temporary work has a significantly different effect on worker earnings from contracting/consulting and other work arrangements. It would be inappropriate, therefore, to aggregate across these categories.

Unique to the NLSY79 is the availability of information on the respondent's Armed Services Vocational Aptitude Battery (ASVAB) test scores. The ASVAB is set of standardized tests used by the military to assess the abilities and knowledge of recruits in the following areas: general science, arithmetic reasoning, word knowledge, paragraph comprehension, numerical operations, coding ability, auto/shop knowledge, mathematics, mechanical comprehension, and electronics. Four separate categories were created in forming proxies for worker ability. Thus, for example, the scores on the word knowledge and paragraph comprehension tests were aggregated. The scores were then regressed on a set of age and education dummies at the time the test was administered, which were allowed to have nonlinear effects. The residuals from this regression were used as a proxy for a worker's verbal ability in the OLS wage regression. Measures of mathematical ability, coding ability, and the catch-all of practical ability were derived in a similar manner. ${ }^{13}$

(Table 7 near here)

The results of the OLS regressions including these observed ability measures are given in Table 7. Although coding ability and mathematical ability are mostly highly significant, they have little effect on the point estimates for the various categories of atypical work. In particular, the strongly negative differential attaching to agency temporary work is practically unchanged (compare Tables 6 and 7). In sum, direct proxies for worker ability - notably math and coding ability - seemingly affect worker earnings but not job choice.

(Table 8 near here) 
However, to test the concern of this paper that ability and employment in an AWA are likely to be negatively correlated for at least some forms of atypical work, we turn to the results of our fixed effect linear estimator. The fitted model is presented in Table 8. The principal result is that the negative differential for temporary work is considerably overstated in absolute terms if we do not control for permanent unobserved individual heterogeneity. To be more precise, the fixed effect model yields a statistically insignificant (negative) coefficient estimate for temporary work. Alternatively put, there are some indications that lower ability workers self select into this work arrangement. The opposite may be more the case for the category of contractors/consultants, the positive point estimate for which is now marginally statistically significant. After taking into consideration worker ability, contracting/consulting work yields a modest five percent premium. Although proxies for ability do not seem to influence job selection, other permanent unobserved differences (e.g. motivation and perseverance) apparently play a big role in reducing earnings differentials.

(Table 9 near here)

We turn finally, to the issue of health insurance benefits. Access to group health insurance (HI) may be of value to a worker given that lower premiums are charged for this type of coverage than is the case for individual (private) polices, even if an employer contributes nothing toward the premium. Descriptive material on access to benefits by type of work arrangement is provided in Table 9. As can be seen, although temporary workers appear to be better off relative to their contracting/consulting counterparts, they are substantially less likely to be offered this benefit than regular workers. Approximately one-third of all temporaries have access to employer-related health insurance, compared to eighty percent of regular workers. Fewer than thirty percent of contractors/consultants can avail themselves of this benefit.

(Tables 10 and 11 near here)

Cross-section estimates of the logit model are given in Table $10 .{ }^{14}$ Temporary workers fare somewhat better than the other atypicals, but they are nonetheless eighteen to twenty-three percentage points less likely to have access to group health insurance than regular employees. Workers engaged in contracting and consulting have yet further reduced access in the range of twenty-six to thirty-eight percentage points. At one level this may not be a surprise (in circumstances where the contractor is the employer) but at another it may be the result of such individuals trading access for the higher earnings observed in our wage analysis. Finally, based 
on the log likelihood statistics presented at the base of the table, we can reject the notion that atypical work has uniform implications for a worker's ability to participate in group coverage

Consistent with the results for earnings, introducing direct proxies for ability in Table 11 does not materially change the probabilities that workers employed in the various work arrangement will have access to health insurance. The main difference is that the proxies for ability now have little explanatory power. Thus, only two of the estimated coefficients are (marginally) significantly different from zero.

(Table 12 near here)

Failing to take into consideration unobserved worker heterogeneity does lead to some potential overstatement of the negative implications of atypical work for a worker's ability to participate in an employer's health insurance program. That is to say, our fixed effect logit estimates - provided in Table 12 - suggest some diminution in the reduced likelihood that atypical workers will have access to health benefits than regular workers. But the effect is rather modest. For example, even in the case of contractors/consultants, the estimated reduction in access relative to regular workers is twenty-seven percentage points as compared with twenty-six to thirty-eight percentage points in cross section.

The main results of our analysis of access to benefits lie elsewhere. First, screened workers are materially more likely to receive this benefit in their compensation packages across all specifications (Tables 10 through 12). The standard logit and the fixed effect logit models yield positive and statistically significant coefficient estimates for screened workers, with the former seemingly now understating the probability that a screened worker will have access to health benefits. Second, failure to control for unobserved worker heterogeneity does produce a clear downward bias on the estimated coefficients of the human capital arguments. That is, the positive effects of experience and tenure on the probability of being offered health insurance are understated in cross section as are the negative effects of a poor work history.

\section{Concluding Remarks}

Our findings echo in part some of the more optimistic, recent treatments of atypical work, despite the appellation which is of course suggestive of poor remuneration. After taking account of unobserved worker heterogeneity, atypical workers do not seemingly receive lower earnings (while some such arrangements actually carry a premium). Nevertheless, atypical workers do 
appear to have reduced access to employer-related health benefits. This is most pronounced in the case of contracting/consulting area, where some of the wage premium is conceivably a compensating differential. Reduced access to benefits on the part of the better known categories of temporary workers may still be a cause for concern and merits further study. In the interstices, however, our broad conclusion is that temporary workers in particular are sorted into arrangements based on their ability. 


\section{Endnotes}

${ }^{1}$ However, as Abraham and Taylor (1996) also point out, technological reasons might underpin contracting out: contractors may be able to realize economies of scale that are simply unavailable in-house. An obvious example of specialized equipment or skills that the small- to medium-sized employers may lack is computer support activities. Here of course there are no negative incomedistributional implications of the growth in alternative work arrangements.

${ }^{2}$ See also Heinrich, Mueser, and Troske (2002) for an evaluation of the use of temporary work by welfare recipients as a means to avoid unemployment.

${ }^{3}$ These observations pertain to employer-related health insurance. A problem with the CPS data is that the questions on the source of health insurance coverage are only asked of those workers who are insured.

${ }^{4}$ As noted by Segal and Sullivan (1998), one key advantage in using the unemployment insurance administrative data over the CPS is that the source of the information on industrial affiliation is the paycheck-issuing entity (for temporary workers, this would be the THS agency). A concern with worker-reported data (as with the outgoing rotations of the CPS) is that agency temporary workers may cite the industrial affiliation of their client firm rather than that of their true employer - the temporary agency. In such cases, researchers will fail to identify temporary workers.

${ }^{5}$ We were unable to use the last CAEAS survey for 2001. Because of a CPS programming error, the survey was not administered to the outgoing rotation group. Labor market data for regular workers, such as wages and industrial/occupational information, are collected only from the outgoing rotation group. Given the programming error, we have no way of distinguishing regular workers from those employed in an AWA.

${ }^{6}$ For those workers not reporting wages on an hourly basis, a wage rate was constructed by dividing their usual weekly earnings by their usual weekly hours.

${ }^{7}$ This last condition led to the inclusion of the miniscule fraction of the agency's workers who are engaged in open-ended employment and are paid by the temporary help service. As noted by Houseman and Polivka (2000), a 1989 Industry Wage Survey indicates that these workers comprise only 3.2 percent of an agency's total employment.

${ }^{8}$ As documented at the foot of Tables 5 and 6 , there is little evidence to suggest that the two forms of temporary employment hold differing implications for a worker's wage. Corresponding tests with respect to health insurance access can be found in Table 10.

${ }^{9}$ The use of an age cohort that is typically older than might be expect to populate alternative work arrangements gives rise to some concern in generalizing our results from the NLSY79. To address this concern, we re-estimated the wage model using the CAEAS/CPS data for the corresponding age cohort. We obtained similar estimates of the cross-section differential as we did when using the NLSY79. 
${ }^{10}$ The NLSY79 contains the actual number of weeks that a respondent has been employed since entering the survey as well as the actual number of weeks employed with the current employer. This allows us to control for general human capital using actual work experience and firmspecific training using a worker's tenure with the employer.

${ }^{11}$ Full results for the CAEAS/CPS pooled sample are reported in Appendix Table 3.

${ }^{12}$ Full results for the 1998 cross section of the NLSY79 are reported in Appendix Table 4.

${ }^{13}$ Construction of the mathematical ability measure first required that we sum across the scores for the respondent's arithmetic reasoning, mathematics, and numerical operations tests. Similarly, practical ability was derived from the general science, auto/shop knowledge, mechanical comprehension, and electronics test scores. The coding measure alone involved no initial summation.

${ }^{14}$ Results for the full HI logit model are reported in Appendix Table 5. 


\section{References}

Abraham, Katherine G. and Susan K. Taylor. "Firms' Use of Outside Contractors: Theory and Evidence.” Journal of Labor Economics 14 (July 1996): 394-424.

Addison, John T. and Christopher J. Surfield. "The Use of Alternative Work Arrangements by the Jobless: Evidence from the CAEAS/CPS." Journal of Labor Research, (2005, forthcoming).

Autor, David H. "Why Do Temporary Help Firms Provide Free General Skills Training?" Quarterly Journal of Economics 116 (November 2001): 1409-49.

Autor, David H. "Outsourcing At Will: the Contribution of Unjust Dismissal Doctrine to the Growth of Employment Outsourcing." Journal of Labor Economics 21 (January 2003): 1-42.

Blank, Rebecca M. "Contingent Work in a Changing Labor Market." In Richard B. Freeman and Peter Gottschalk, eds., Generating Jobs: How to Increase Demand for Less-Skilled Workers. New York: Russell Sage Foundation, 1998, pp. 258-94.

Cohany, Sharon R. "Workers in Alternative Employment Arrangements: A Second Look." Monthly Labor Review 121 (November 1998): 3-21.

Farber, Henry S. "Alternative and Part-Time Employment Arrangements as a Response to Job Loss." Journal of Labor Economics 17 (October 1999): S142-69.

Heinrich, Carolyn J., Peter R. Mueser, and Kenneth Troske. "Welfare to Temporary Work: Implications for Labor Market Outcomes.” IZA Working Paper \#584, September 2002.

Hipple, Steven and Jay Stewart. "Earnings and Benefits of Workers in Alternative Work Arrangements." Monthly Labor Review 119 (October 1996): 46-54.

Houseman, Susan N. and Anne E. Polivka. "The Implications of Flexible Staffing Arrangements for Job Security." In David Neumark, ed. On the Job: Is Long-Term Employment a Thing of the Past? New York: Russell Sage Foundation, 2000, pp. 427-62.

Nollen, Stanley D. "Negative Aspects of Temporary Employment." Journal of Labor Research 27 (Fall 1996): 567-82.

Rothstein, Donna S. "Entry Into and Consequences of Nonstandard Work Arrangements." Monthly Labor Review 119 (October 1996): 76 -83

Segal, Lewis M. and Daniel G. Sullivan. "The Growth of Temporary Services Work." Journal of Economic Perspectives 11 (Spring 1997): 117-36.

Segal, Lewis M. and Daniel G. Sullivan. "Wage Differentials for Temporary Services Work: Evidence from Administrative Data." Federal Reserve Bank of Chicago Working Paper WP-9823, December 1998. 
United States Department of Labor. "Employer Costs for Employee Compensation - March 2002.” Press Release USDL \#02-346, July 2002. 


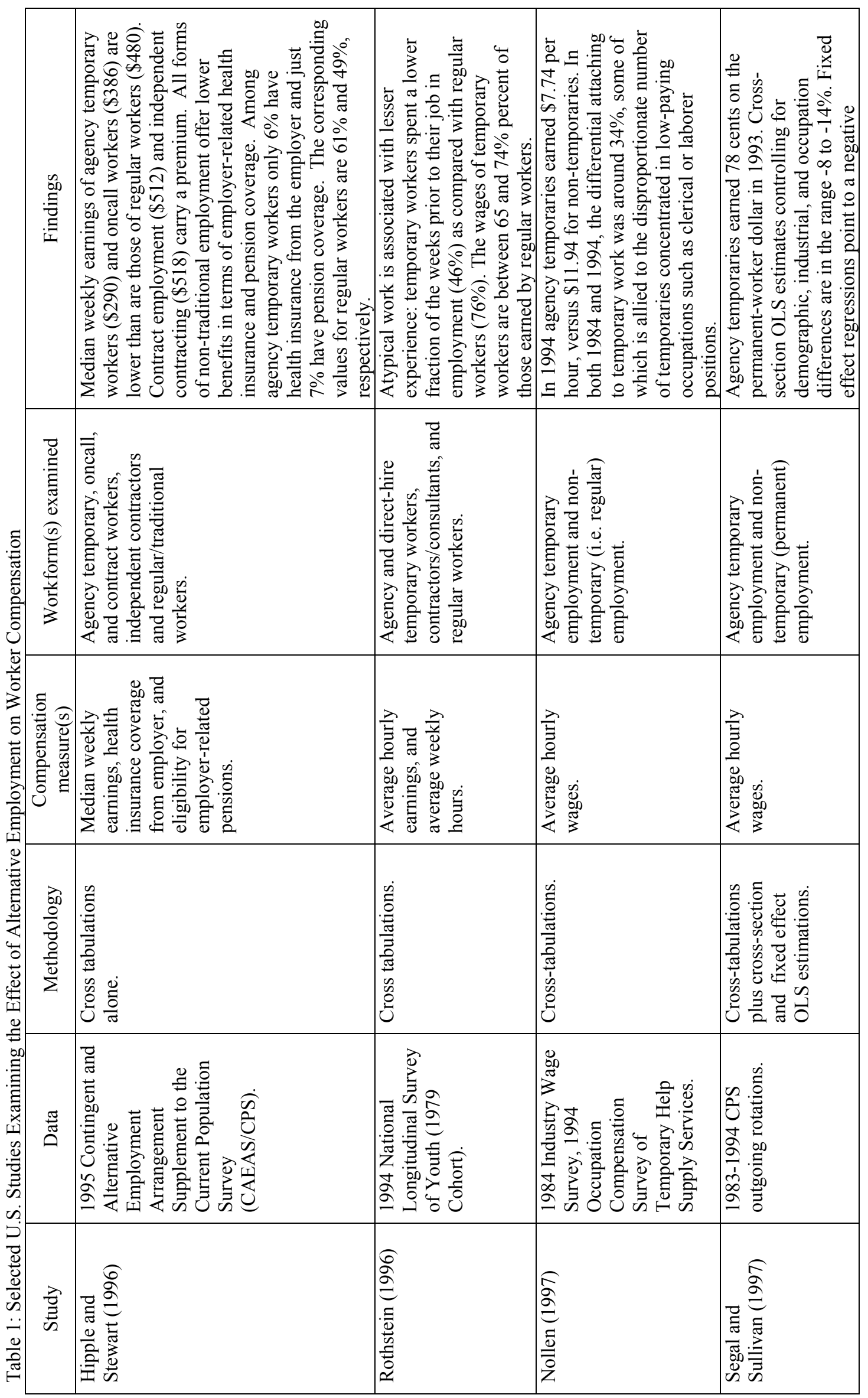




\begin{tabular}{|c|c|c|c|c|c|}
\hline 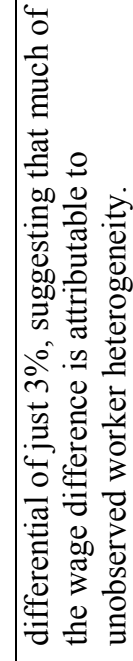 & 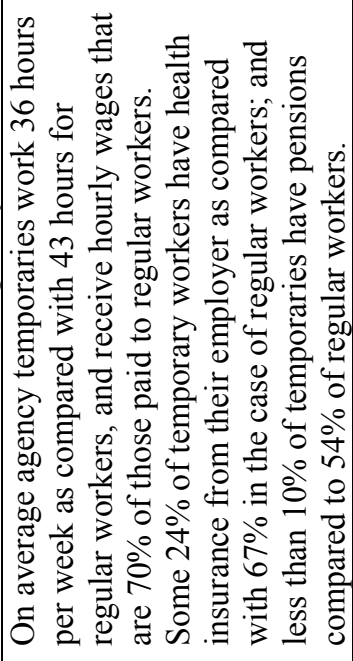 & 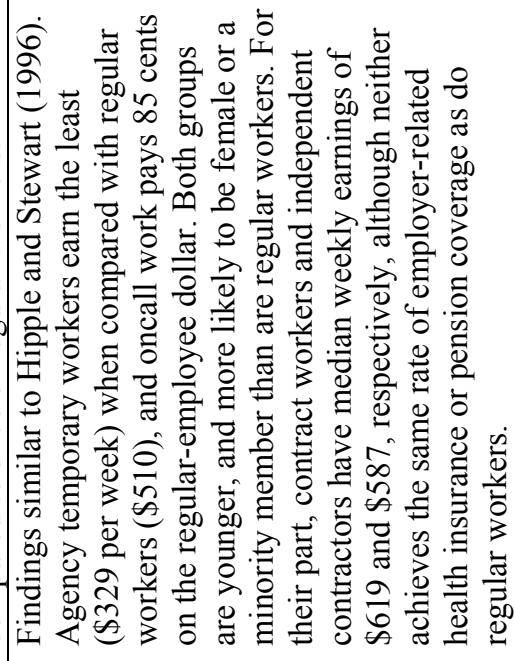 & 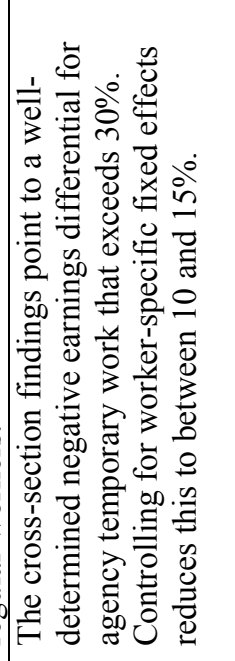 & 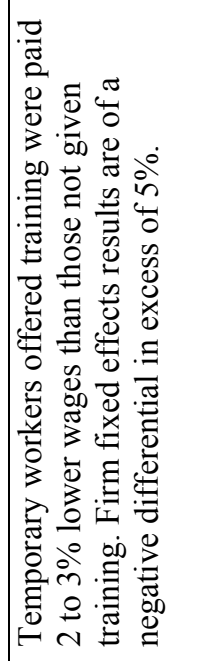 & 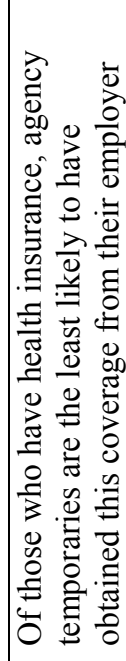 \\
\hline & 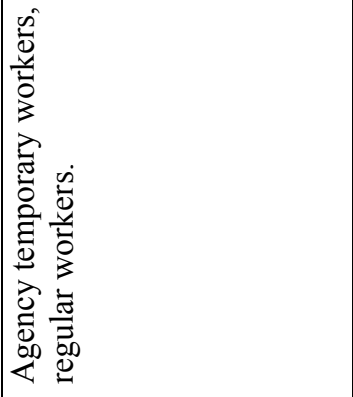 & 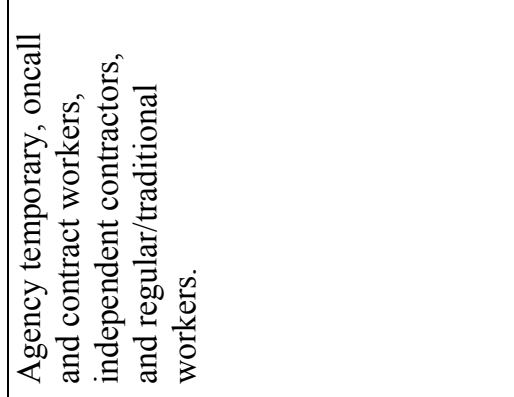 & 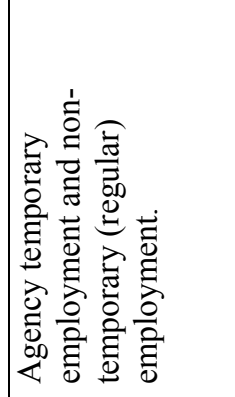 & 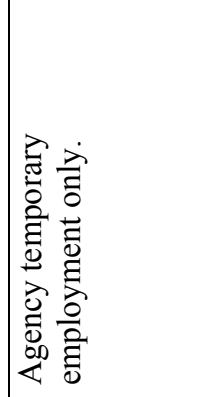 & 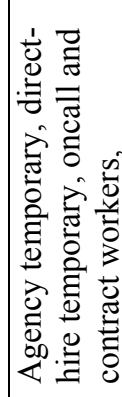 \\
\hline & 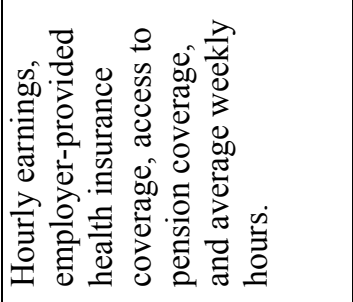 & 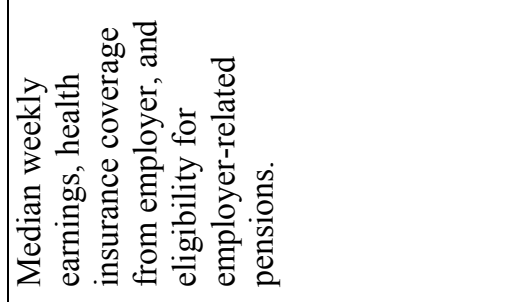 & 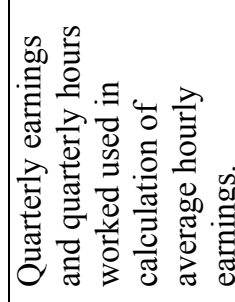 & 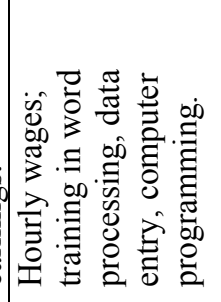 & 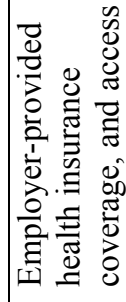 \\
\hline & 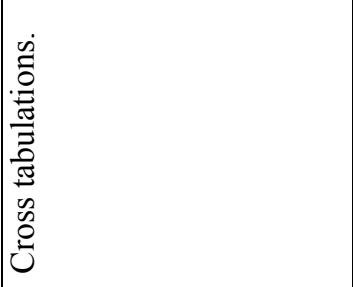 & 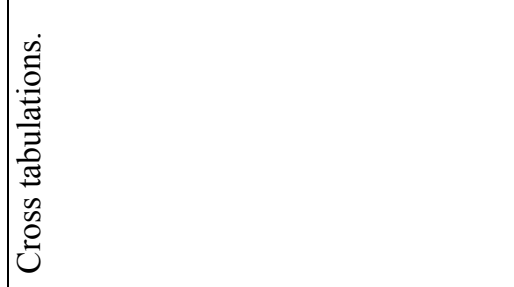 & 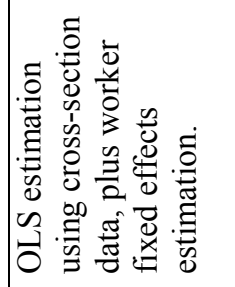 & 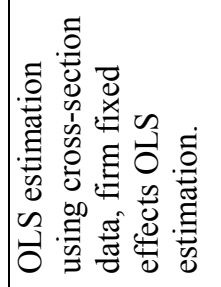 & 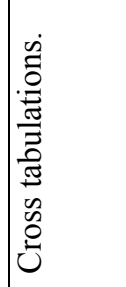 \\
\hline & 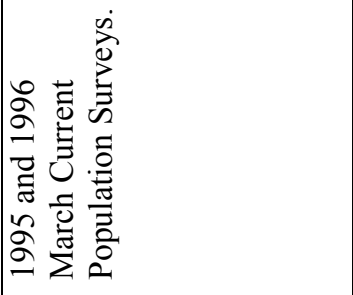 & 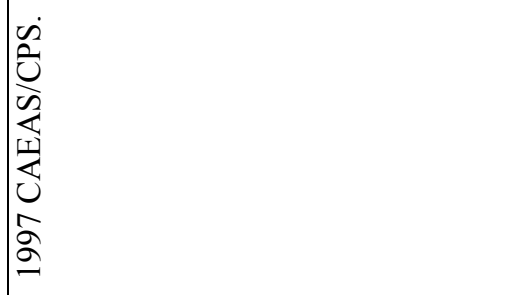 & 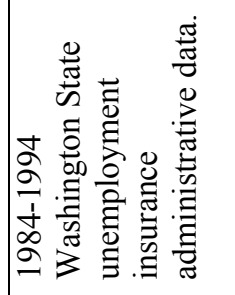 & 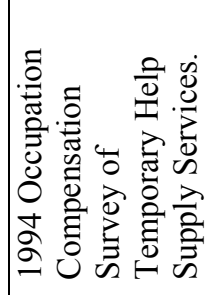 & 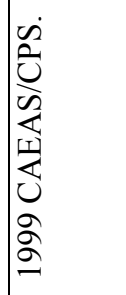 \\
\hline & 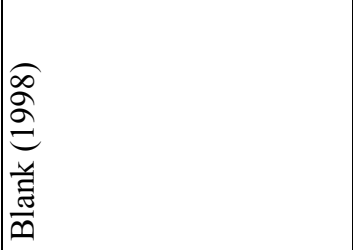 & 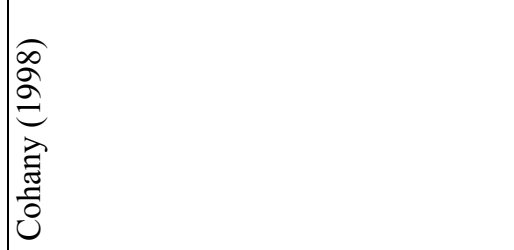 & 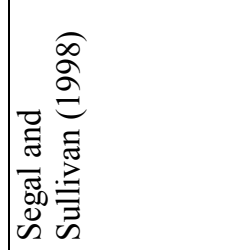 & 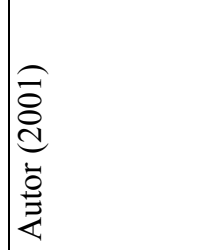 & 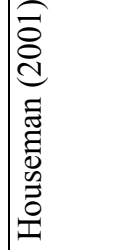 \\
\hline
\end{tabular}




\begin{tabular}{|c|c|}
\hline 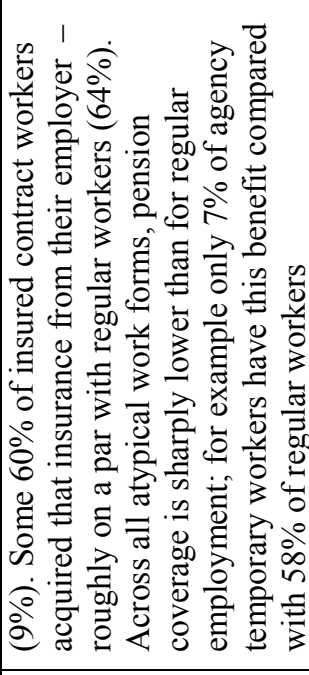 & 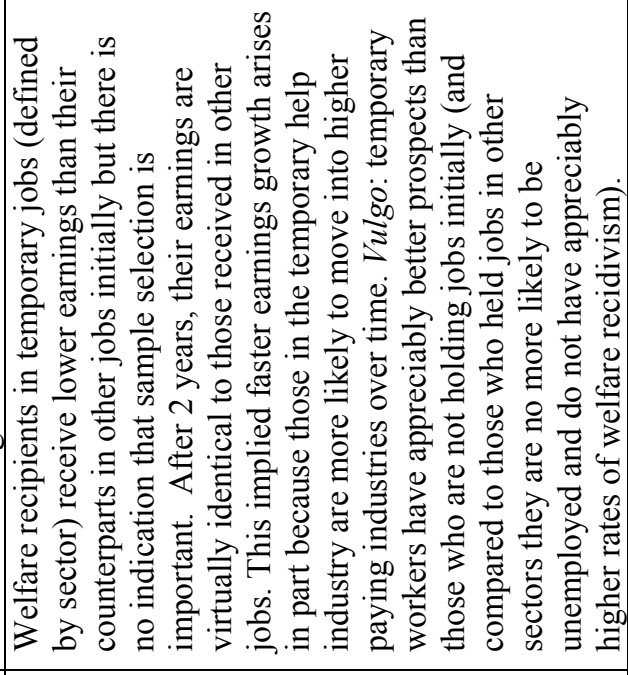 \\
\hline 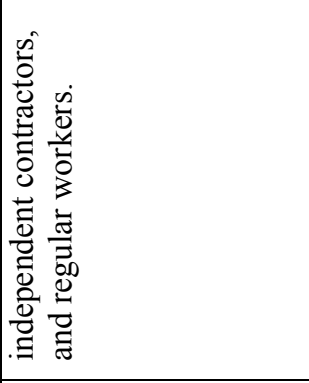 & 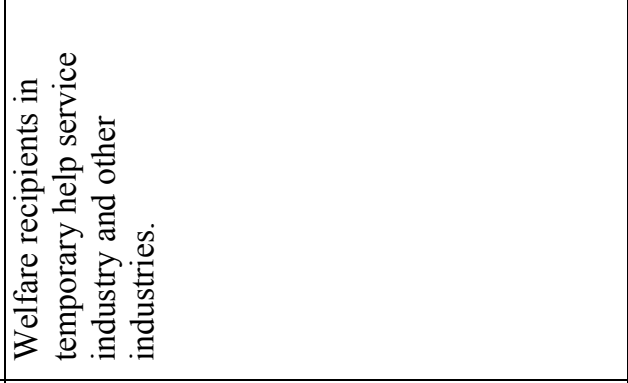 \\
\hline \multirow[t]{4}{*}{ 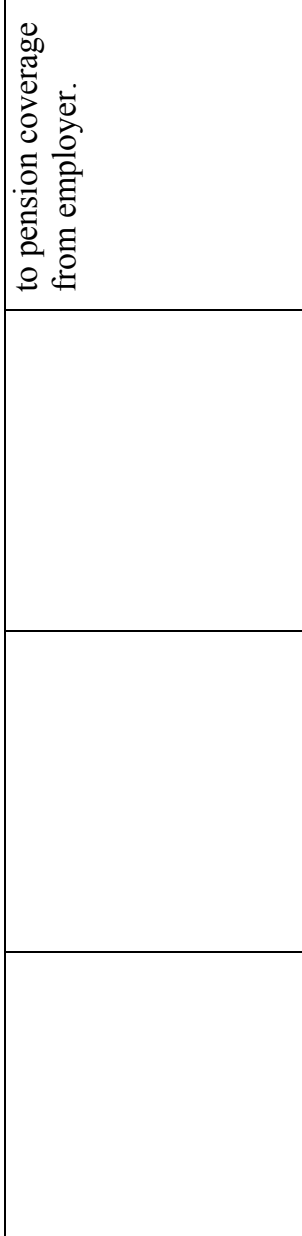 } & 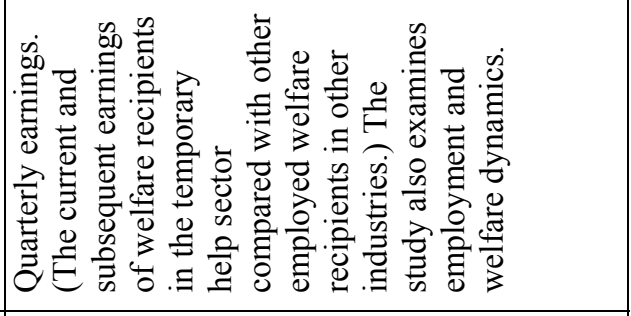 \\
\hline & 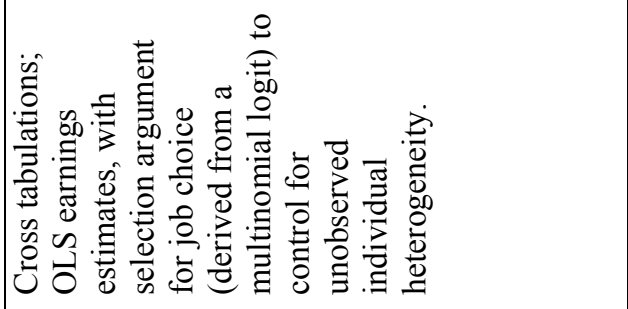 \\
\hline & 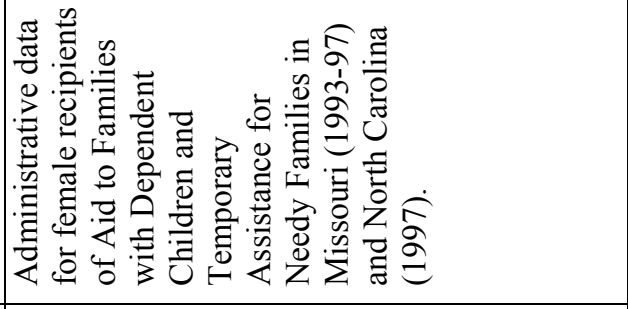 \\
\hline & 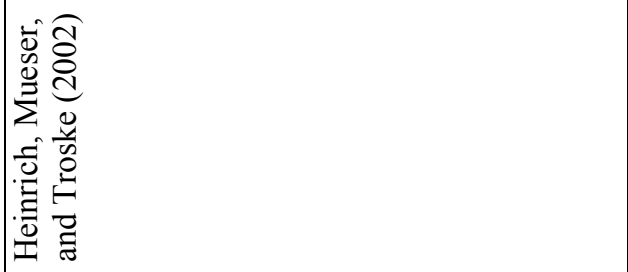 \\
\hline
\end{tabular}


Table 2: Hourly Wage Rates by Employment Arrangement (CAEAS/CPS Data)

\begin{tabular}{lccc}
\hline & 1995 & 1997 & 1999 \\
\hline Regular & 13.35 & 14.23 & 15.31 \\
workers & $(8.45)$ & $(8.38)$ & $(9.65)$ \\
Screened & 13.38 & 14.51 & 16.46 \\
workers & $(7.20)$ & $(6.83)$ & $(10.20)$ \\
Temporary & 13.02 & 12.25 & 12.85 \\
workers & $(9.32)$ & $(8.91)$ & $(9.59)$ \\
Oncall & 11.04 & 11.39 & 12.74 \\
workers & $(9.23)$ & $(6.82)$ & $(8.95)$ \\
Contract & 14.49 & 14.91 & 23.82 \\
workers & $(6.95)$ & $(9.53)$ & $(17.47)$ \\
Independent & 16.13 & 21.29 & 23.02 \\
contractors & $(12.87)$ & $(19.37)$ & $(19.24)$ \\
$n$ & 11,438 & 11,585 & 11,732 \\
\hline
\end{tabular}

Note: Results are reported as means and standard deviations (in parentheses).

Table 3: Hourly Wage Rates by Employment Arrangement (NLSY79 Data)

\begin{tabular}{lccc}
\hline & 1994 & 1996 & 1998 \\
\hline $\begin{array}{l}\text { Regular } \\
\text { workers }\end{array}$ & 13.41 & 14.65 & $(10.72)$ \\
Screened & $(9.03)$ & $(10.15)$ & 15.31 \\
workers & 12.88 & 15.10 & $(7.49)$ \\
Temporary & $(7.48)$ & $(9.61)$ & 9.53 \\
workers & 8.86 & 9.18 & $(5.19)$ \\
Contractors/ & $(4.44)$ & $(5.12)$ & 20.89 \\
consultants & 14.19 & 21.12 & $(15.36)$ \\
Other work & $(10.89)$ & $(18.89)$ & 17.14 \\
types & 19.62 & 19.67 & $(6.99)$ \\
$n$ & $(15.83)$ & $(17.73)$ & 6,054 \\
\hline
\end{tabular}

Note: See Notes to Table 2. 
Table 4: Labor Market Experience by Employment Arrangement (1994 NLSY79 Data)

\begin{tabular}{lccccc}
\hline & $\begin{array}{c}\text { Regular } \\
\text { workers }\end{array}$ & $\begin{array}{c}\text { Screened } \\
\text { workers }\end{array}$ & $\begin{array}{c}\text { Temporary } \\
\text { workers }\end{array}$ & $\begin{array}{c}\text { Consultants/ } \\
\text { contractors }\end{array}$ & $\begin{array}{c}\text { Other work } \\
\text { types }\end{array}$ \\
\hline $\begin{array}{l}\text { Experience } \\
\text { (in years) }\end{array}$ & 12.98 & 12.62 & 10.17 & 12.65 & 13.06 \\
Tenure & $(3.35)$ & $(3.24)$ & $(3.96)$ & $(3.80)$ & $(3.60)$ \\
(in years) & 5.20 & 5.01 & 1.24 & 3.96 & 2.10 \\
Jobs & $(4.50)$ & $(4.17)$ & $(2.12)$ & $(3.85)$ & $(2.35)$ \\
& 0.78 & 0.84 & 1.54 & 0.98 & 1.08 \\
$n$ & $(0.57)$ & $(0.57)$ & $(1.21)$ & $(0.55)$ & $(0.54)$ \\
& 5,100 & 444 & 114 & 87 & 31 \\
\hline
\end{tabular}

Note: See Notes to Table 2. 


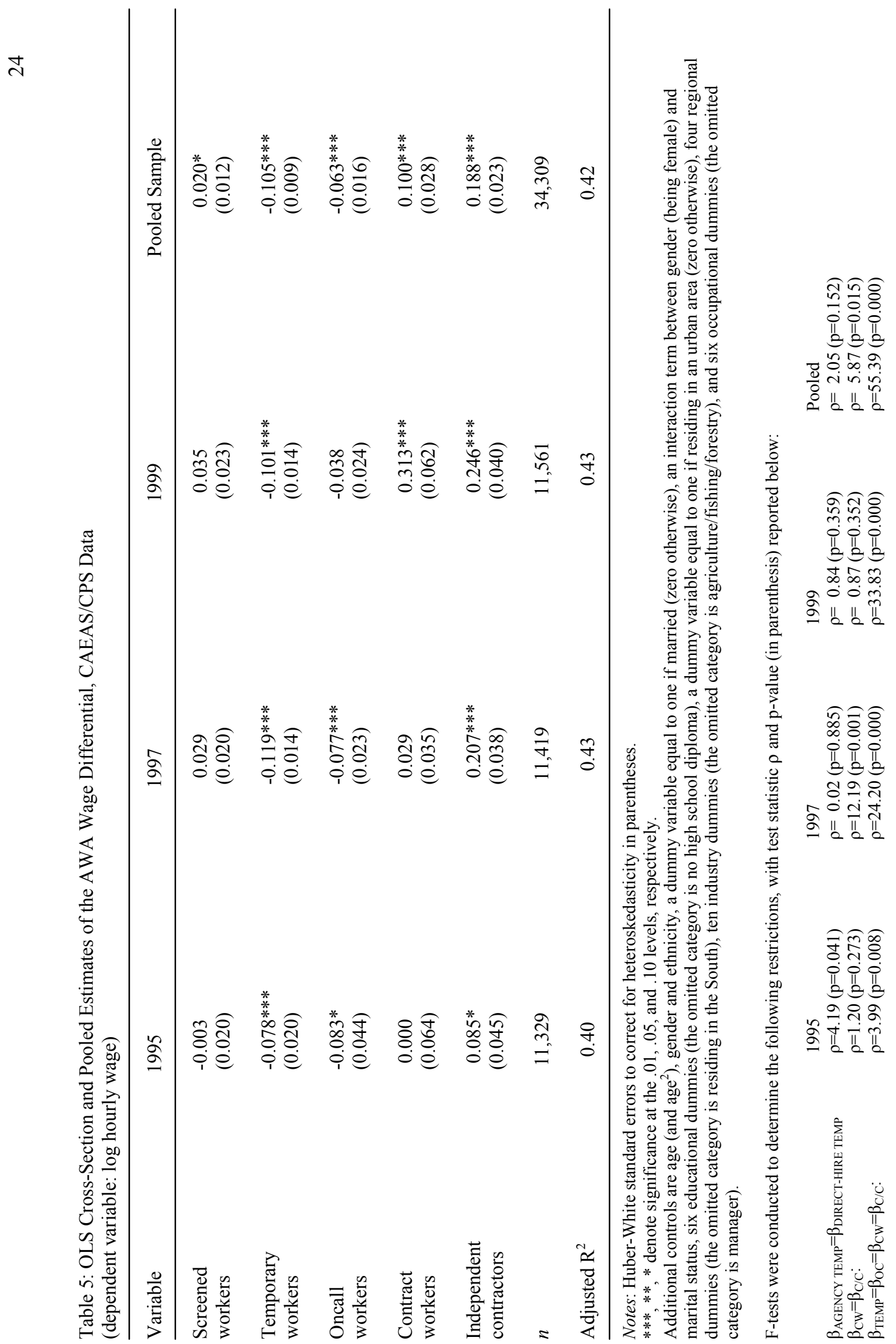


Table 6: OLS Cross-Section Estimates of the AWA Wage Differential, NLSY79 Data (dependent variable: log hourly wage)

\begin{tabular}{|c|c|c|c|}
\hline Variable & 1994 & 1996 & 1998 \\
\hline $\begin{array}{l}\text { Screened } \\
\text { workers }\end{array}$ & $\begin{array}{l}-0.004 \\
(0.018)\end{array}$ & $\begin{array}{l}0.045^{* *} \\
(0.021)\end{array}$ & $\begin{array}{c}0.019 \\
(0.018)\end{array}$ \\
\hline $\begin{array}{l}\text { Temporary } \\
\text { workers }\end{array}$ & $\begin{array}{l}-0.073 * \\
(0.043)\end{array}$ & $\begin{array}{l}-0.078 * \\
(0.043)\end{array}$ & $\begin{array}{l}-0.118 * * * \\
(0.044)\end{array}$ \\
\hline $\begin{array}{l}\text { Contractors/ } \\
\text { consultants }\end{array}$ & $\begin{array}{c}0.018 \\
(0.076)\end{array}$ & $\begin{array}{c}0.131 * \\
(0.077)\end{array}$ & $\begin{array}{c}0.046 \\
(0.058)\end{array}$ \\
\hline $\begin{array}{l}\text { Other work } \\
\text { types }\end{array}$ & $\begin{array}{c}0.124 \\
(0.092)\end{array}$ & $\begin{array}{c}0.204 \\
(0.137)\end{array}$ & $\begin{array}{c}0.090 \\
(0.058)\end{array}$ \\
\hline $\begin{array}{l}\text { Jobs } \\
\text { (standardized) }\end{array}$ & $\begin{array}{l}-0.021^{*} \\
(0.013)\end{array}$ & $\begin{array}{l}-0.022 * \\
(0.013)\end{array}$ & $\begin{array}{l}-0.018 \\
(0.014)\end{array}$ \\
\hline Experience & $\begin{array}{c}0.006 \\
(0.009)\end{array}$ & $\begin{array}{c}0.003 \\
(0.008)\end{array}$ & $\begin{array}{c}0.006 \\
(0.007)\end{array}$ \\
\hline Experience $^{2}$ & $\begin{array}{l}0.001 * * \\
(0.000)\end{array}$ & $\begin{array}{l}0.001^{* *} \\
(0.000)\end{array}$ & $\begin{array}{l}0.001 * * \\
(0.000)\end{array}$ \\
\hline Tenure & $\begin{array}{l}0.040 * * * \\
(0.004)\end{array}$ & $\begin{array}{l}0.037 * * * \\
(0.004)\end{array}$ & $\begin{array}{l}0.037 * * * \\
(0.003)\end{array}$ \\
\hline Tenure $^{2}$ & $\begin{array}{l}-0.002 * * * \\
(0.000)\end{array}$ & $\begin{array}{l}-0.002 * * * \\
(0.000)\end{array}$ & $\begin{array}{l}-0.001 * * * \\
(0.000)\end{array}$ \\
\hline$n$ & 5,776 & 5,955 & 6,054 \\
\hline Adjusted $\mathrm{R}^{2}$ & 0.40 & 0.42 & 0.45 \\
\hline
\end{tabular}

Notes: Huber-White standard errors to correct for heteroskedasticity in parentheses.

$* * *, * *, *$ denote significance at the $.01, .05$, and .10 levels, respectively.

Additional controls are age (and $\operatorname{age}^{2}$ ), gender and ethnicity, a dummy variable equal to one if married (zero otherwise), an interaction term between gender (being female) and marital status, education (in years), a dummy variable equal to one if residing in an urban area (zero otherwise), four regional dummies (the omitted category is residing in the South), ten industry dummies (the omitted category is agriculture/fishing/forestry), and six occupational dummies (the omitted category is manager).

F-tests were conducted to determine the following restrictions, with test statistic $\rho$ and p-value (in parentheses) reported below:

$\begin{array}{llll} & 1994 & 1996 & 1998 \\ \beta_{\text {AGENCY TEMP }}=\beta_{\text {DIRECT-HIRE TEMP }} & \rho=3.74(\mathrm{p}=0.053) & \rho=0.19(\mathrm{p}=0.660) & \rho=3.29(\mathrm{p}=0.070) \\ \beta_{\text {TEMP }}=\beta_{\mathrm{C} / \mathrm{C}}=\beta_{\text {OTHER }} & \rho=2.71(\mathrm{p}=0.043) & \rho=2.83(\mathrm{p}=0.037) & \rho=5.28(\mathrm{p}=0.001)\end{array}$


Table 7: OLS Cross-Section Estimates of the Wage Differential Using Ability Proxies, NLSY79 Data (dependent variable: log hourly wage)

\begin{tabular}{lccc}
\hline Variable & 1994 & 1996 & 1998 \\
\hline Screened & -0.009 & $0.042^{* *}$ & 0.022 \\
workers & $(0.018)$ & $(0.021)$ & $(0.018)$ \\
Temporary & $-0.072^{*}$ & $-0.089^{* *}$ & $-0.110^{* *}$ \\
workers & $(0.043)$ & $(0.0 .44)$ & $(0.046)$ \\
Contractors/ & 0.037 & 0.106 & 0.078 \\
consultants & $(0.072)$ & $(0.080)$ & $(0.061)$ \\
Other work & 0.127 & $0.243^{*}$ & 0.082 \\
types & $(0.102)$ & $(0.135)$ & $(0.060)$ \\
Coding & $0.023^{* * *}$ & 0.010 & $0.019^{* * *}$ \\
ability & $(0.007)$ & $(0.007)$ & $(0.007)$ \\
Mathematical & $0.045^{* * *}$ & $0.057^{* * *}$ & $0.047 * * *$ \\
ability & $(0.011)$ & $(0.011)$ & $(0.011)$ \\
Practical & 0.011 & $0.022^{*}$ & 0.005 \\
ability & $(0.013)$ & $(0.013)$ & $(0.012)$ \\
Verbal & 0.005 & 0.006 & 0.016 \\
ability & $(0.011)$ & $(0.011)$ & $(0.010)$ \\
$n$ & 5,488 & 5,673 & 5,758 \\
Adjusted $\mathrm{R}^{2}$ & 0.41 & 0.44 & 0.46 \\
\hline
\end{tabular}

Notes: See text and Notes to Table 6. 
Table 8: Fixed Effect OLS Estimates of the Wage Differential, NLSY79 Data (dependent variable: log hourly wage)

\begin{tabular}{|c|c|}
\hline Variable & $\begin{array}{c}\text { Coefficent } \\
\text { (standard error) }\end{array}$ \\
\hline $\begin{array}{l}\text { Screened } \\
\text { workers }\end{array}$ & $\begin{array}{c}0.018 \\
(0.013)\end{array}$ \\
\hline $\begin{array}{l}\text { Temporary } \\
\text { workers }\end{array}$ & $\begin{array}{l}-0.026 \\
(0.025)\end{array}$ \\
\hline $\begin{array}{l}\text { Contractors/ } \\
\text { consultants }\end{array}$ & $\begin{array}{c}0.050 * \\
(0.026)\end{array}$ \\
\hline $\begin{array}{l}\text { Other work } \\
\text { types }\end{array}$ & $\begin{array}{l}0.089 * * \\
(0.043)\end{array}$ \\
\hline $\begin{array}{l}\text { Jobs } \\
\text { (standardized) }\end{array}$ & $\begin{array}{l}-0.023 \\
(0.019)\end{array}$ \\
\hline Experience & $\begin{array}{l}0.077 * * * \\
(0.015)\end{array}$ \\
\hline Experience $^{2}$ & $\begin{array}{l}-0.000 \\
(0.000)\end{array}$ \\
\hline Tenure & $\begin{array}{l}0.017 * * * \\
(0.003)\end{array}$ \\
\hline Tenure $^{2}$ & $\begin{array}{l}-0.001 * * * \\
(0.000)\end{array}$ \\
\hline$n$ & 17,785 \\
\hline Adjusted $\mathrm{R}^{2}$ & 0.26 \\
\hline
\end{tabular}

Notes: $* * * * * *$ denote significance at the $.01, .05$, and .10 levels, respectively.

Additional controls are age (and age ${ }^{2}$ ), a dummy variable equal to one if married (zero otherwise), an interaction term between gender (being female) and marital status, education (in years), a dummy variable equal to one if residing in an urban area (zero otherwise), four regional dummies (omitted category is residing in the South), ten industrial dummies (omitted category is working in agriculture/fishing/forestry), and six occupational dummies (omitted category is employment as a manager). 
Table 9: Availability of Employer-Related Health Insurance by Employment Arrangement, NLSY79 Data (in percent)

\begin{tabular}{llll}
\hline & 1994 & 1996 & 1998 \\
\hline Regular workers & $79.9 \%$ & $80.9 \%$ & $83.1 \%$ \\
Screened workers & 90.7 & 86.6 & 88.7 \\
Temporary workers & 33.3 & 32.4 & 42.8 \\
Contractors/consultants & 18.9 & 28.8 & 29.5 \\
Other work types & 39.7 & 43.5 & 75.3 \\
$n$ & 5,587 & 5,649 & 5,639 \\
\hline
\end{tabular}


Table 10: Logit Estimates of Access to Employer-Related Health Insurance Benefits, NLSY79 Data

\begin{tabular}{|c|c|c|c|}
\hline Variable & 1994 & 1996 & 1998 \\
\hline $\begin{array}{l}\text { Screened } \\
\text { workers }\end{array}$ & $\begin{array}{l}0.527^{* * *} \\
(0.166) \\
{[0.068]}\end{array}$ & $\begin{array}{l}0.430^{* * *} \\
(0.158) \\
{[0.053]}\end{array}$ & $\begin{array}{l}0.593 * * * \\
(0.185) \\
{[0.065]}\end{array}$ \\
\hline $\begin{array}{l}\text { Temporary } \\
\text { workers }\end{array}$ & $\begin{array}{l}-1.752 * * * \\
(0.263) \\
{[-0.226]}\end{array}$ & $\begin{array}{l}-1.616^{* * *} \\
(0.277) \\
{[-0.200]}\end{array}$ & $\begin{array}{l}-1.602 * * * \\
(0.277) \\
{[-0.175]}\end{array}$ \\
\hline $\begin{array}{l}\text { Contractors/ } \\
\text { consultants }\end{array}$ & $\begin{array}{l}-2.944 * * * \\
(0.327) \\
{[-0.379]}\end{array}$ & $\begin{array}{l}-2.437 * * * \\
(0.316) \\
{[-0.301]}\end{array}$ & $\begin{array}{l}-2.344 * * * \\
(0.356) \\
{[-0.257]}\end{array}$ \\
\hline $\begin{array}{l}\text { Other work } \\
\text { types }\end{array}$ & $\begin{array}{l}-1.257^{* * *} \\
(0.468) \\
{[-0.162]}\end{array}$ & $\begin{array}{c}-1.040^{*} \\
(0.556) \\
{[-0.129]}\end{array}$ & $\begin{array}{c}-0.263 \\
(0.419) \\
{[-0.029]}\end{array}$ \\
\hline $\begin{array}{l}\text { Jobs } \\
\text { (standardized) }\end{array}$ & $\begin{array}{c}-0.131 \\
(0.078) \\
{[-0.015]}\end{array}$ & $\begin{array}{c}-0.142^{*} \\
(0.077) \\
{[-0.018]}\end{array}$ & $\begin{array}{l}-0.224 * * \\
(0.087) \\
{[-0.033]}\end{array}$ \\
\hline Experience & $\begin{array}{c}-0.084 \\
(0.058) \\
{[-0.011]}\end{array}$ & $\begin{array}{c}-0.017 \\
(0.048) \\
{[-0.002]}\end{array}$ & $\begin{array}{c}0.040 \\
(0.044) \\
{[0.040]}\end{array}$ \\
\hline Experience $^{2}$ & $\begin{array}{l}0.007 * * \\
(0.003) \\
{[0.001]}\end{array}$ & $\begin{array}{l}0.004 * * \\
(0.002) \\
{[0.001]}\end{array}$ & $\begin{array}{c}0.001 \\
(0.002) \\
{[0.000]}\end{array}$ \\
\hline Tenure & $\begin{array}{l}0.295^{* * *} \\
(0.031) \\
{[0.038]}\end{array}$ & $\begin{array}{l}0.154 * * * \\
(0.029) \\
{[0.019]}\end{array}$ & $\begin{array}{l}0.147 * * * \\
(0.028) \\
{[0.016]}\end{array}$ \\
\hline Tenure $^{2}$ & $\begin{array}{l}-0.013^{* * *} \\
(0.002) \\
{[-0.002]}\end{array}$ & $\begin{array}{l}-0.005^{* * *} \\
(0.002) \\
{[-0.001]}\end{array}$ & $\begin{array}{l}-0.004 * * \\
(0.002) \\
{[-0.000]}\end{array}$ \\
\hline$n$ & 5,587 & 5,649 & 5,639 \\
\hline $\log L$ & $-2,232.89$ & $-2,268.19$ & $-2,137.15$ \\
\hline
\end{tabular}

Notes: Standard errors are given in parentheses and marginal effects in brackets.

$* * *, * * *$ denote significance at the $.01, .05$, and .10 levels, respectively.

Additional controls are age (and age ${ }^{2}$ ), gender and ethnicity, a dummy variable equal to one if married (zero otherwise), an interaction term between gender (being female) and marital status, education (in years), a dummy variable equal to one if residing in an urban area (zero otherwise), four regional dummies (the omitted category is residing in the South), ten industry dummies (the omitted category is agriculture/fishing/forestry), and six occupational dummies (the omitted category is manager).

Likelihood ratio tests were conducted to determine the following restrictions, with test statistic $\rho$ and p-value (in parentheses) reported below:

$\begin{array}{llll} & 1994 & 1996 & 1998 \\ \beta_{\text {AGENCY TEMP }}=\beta_{\text {DIRECT-HIRE TEMP }} & \rho=0.05(\mathrm{p}=0.825) & \rho=0.62(\mathrm{p}=0.430) & \rho=0.17(\mathrm{p}=0.677) \\ \beta_{\text {TEMP }}=\beta_{\mathrm{C} / \mathrm{C}}=\beta_{\text {OTHER }} & \rho=12.44(\mathrm{p}=0.006) & \rho=7.07(\mathrm{p}=0.070) & \rho=15.98(\mathrm{p}=0.001)\end{array}$


Table 11: Logit Estimates of Access to Employer-Related Health Insurance Benefits Using Ability Proxies, NLSY79 data

\begin{tabular}{|c|c|c|c|}
\hline Variable & 1994 & 1996 & 1998 \\
\hline $\begin{array}{l}\text { Screened } \\
\text { workers }\end{array}$ & $\begin{array}{l}0.495^{* * * *} \\
(0.170) \\
{[0.062]}\end{array}$ & $\begin{array}{l}0.517 * * * \\
(0.167) \\
{[0.063]}\end{array}$ & $\begin{array}{l}0.572 * * * \\
(0.188) \\
{[0.061]}\end{array}$ \\
\hline $\begin{array}{l}\text { Temporary } \\
\text { workers }\end{array}$ & $\begin{array}{l}-1.784 * * * \\
(0.269) \\
{[-0.225]}\end{array}$ & $\begin{array}{l}-1.537 * * * \\
(0.285) \\
{[-0.187]}\end{array}$ & $\begin{array}{l}-1.623 * * * \\
(0.283) \\
{[-0.174]}\end{array}$ \\
\hline $\begin{array}{l}\text { Contractors/ } \\
\text { consultants }\end{array}$ & $\begin{array}{l}-3.131 * * * \\
(0.352) \\
{[-0.395]}\end{array}$ & $\begin{array}{l}-2.579 * * * \\
(0.327) \\
{[-0.314]}\end{array}$ & $\begin{array}{l}-2.293 * * * \\
(0.388) \\
{[-0.245]}\end{array}$ \\
\hline $\begin{array}{l}\text { Other work } \\
\text { types }\end{array}$ & $\begin{array}{c}-0.994 * \\
(0.519) \\
{[-0.125]}\end{array}$ & $\begin{array}{c}-1.341 * * \\
(0.620) \\
{[-0.163]}\end{array}$ & $\begin{array}{c}-0.397 \\
(0.429) \\
{[-0.042]}\end{array}$ \\
\hline Coding ability & $\begin{array}{c}0.068 \\
(0.050) \\
{[0.008]}\end{array}$ & $\begin{array}{c}0.058 \\
(0.050) \\
{[0.007]}\end{array}$ & $\begin{array}{c}0.001 \\
(0.052) \\
{[0.000]}\end{array}$ \\
\hline Mathematical ability & $\begin{array}{c}-0.085 \\
(0.076) \\
{[-0.011]}\end{array}$ & $\begin{array}{c}-0.033 \\
(0.077) \\
{[-0.004]}\end{array}$ & $\begin{array}{c}0.056 \\
(0.079) \\
{[0.006]}\end{array}$ \\
\hline Practical ability & $\begin{array}{c}0.152 * \\
(0.087) \\
{[0.019]}\end{array}$ & $\begin{array}{c}0.054 \\
(0.087) \\
{[0.007]}\end{array}$ & $\begin{array}{c}0.043 \\
(0.091) \\
{[0.005]}\end{array}$ \\
\hline Verbal ability & $\begin{array}{c}0.041 \\
(0.073) \\
{[0.005]}\end{array}$ & $\begin{array}{c}0.127^{*} \\
(0.072) \\
{[0.015]}\end{array}$ & $\begin{array}{c}0.091 \\
(0.076) \\
{[0.010]}\end{array}$ \\
\hline$n$ & 5,310 & 5,386 & 5,365 \\
\hline $\log \mathrm{L}$ & $-2,099.35$ & $-2,137.15$ & $-2,012.59$ \\
\hline
\end{tabular}

Notes: See Table 10. 
Table 12: FE Logit Estimates of Access to Employer-Related Health Insurance Benefits, NLSY79 data

\begin{tabular}{|c|c|}
\hline Variable & $\begin{array}{c}\text { Coefficient } \\
\text { (standard error) } \\
\text { [marginal effect }]\end{array}$ \\
\hline $\begin{array}{l}\text { Screened } \\
\text { workers }\end{array}$ & $\begin{array}{l}0.583 * * * \\
(0.196) \\
{[0.094]}\end{array}$ \\
\hline $\begin{array}{l}\text { Temporary } \\
\text { workers }\end{array}$ & $\begin{array}{l}-1.310 * * * \\
(0.297) \\
{[-0.210]}\end{array}$ \\
\hline $\begin{array}{l}\text { Contractors/ } \\
\text { consultants }\end{array}$ & $\begin{array}{c}-1.681 * * * \\
(0.405) \\
{[-0.270]}\end{array}$ \\
\hline $\begin{array}{l}\text { Other work } \\
\text { types }\end{array}$ & $\begin{array}{c}-0.936 \\
(0.676) \\
{[-0.150]}\end{array}$ \\
\hline $\begin{array}{l}\text { Jobs } \\
\text { (standardized) }\end{array}$ & $\begin{array}{c}-0.087 \\
(0.414) \\
{[-0.014]}\end{array}$ \\
\hline Experience & $\begin{array}{l}0.371 * \\
(0.211) \\
{[0.060]}\end{array}$ \\
\hline Experience $^{2}$ & $\begin{array}{c}-0.000 \\
(0.004) \\
{[-0.000]}\end{array}$ \\
\hline Tenure & $\begin{array}{l}0.360 * * * \\
(0.046) \\
{[0.058]}\end{array}$ \\
\hline Tenure $^{2}$ & $\begin{array}{l}-0.023 * * * \\
(0.004) \\
{[-0.004]}\end{array}$ \\
\hline$n$ & 2,987 \\
\hline $\log L$ & -911.71 \\
\hline
\end{tabular}

Notes: $* * * * * *$ denote significance at the $.01, .05$, and .10 levels, respectively.

Additional controls are age (and age ${ }^{2}$ ), a dummy variable equal to one if married (zero otherwise), an interaction term between gender (being female) and marital status, education (in years), a dummy variable equal to one if residing in an urban area (zero otherwise), four regional dummies (the omitted category is residing in the south), ten industry dummies (the omitted category is agriculture/fishing/forestry), and six occupational dummies (the omitted category is manager). 


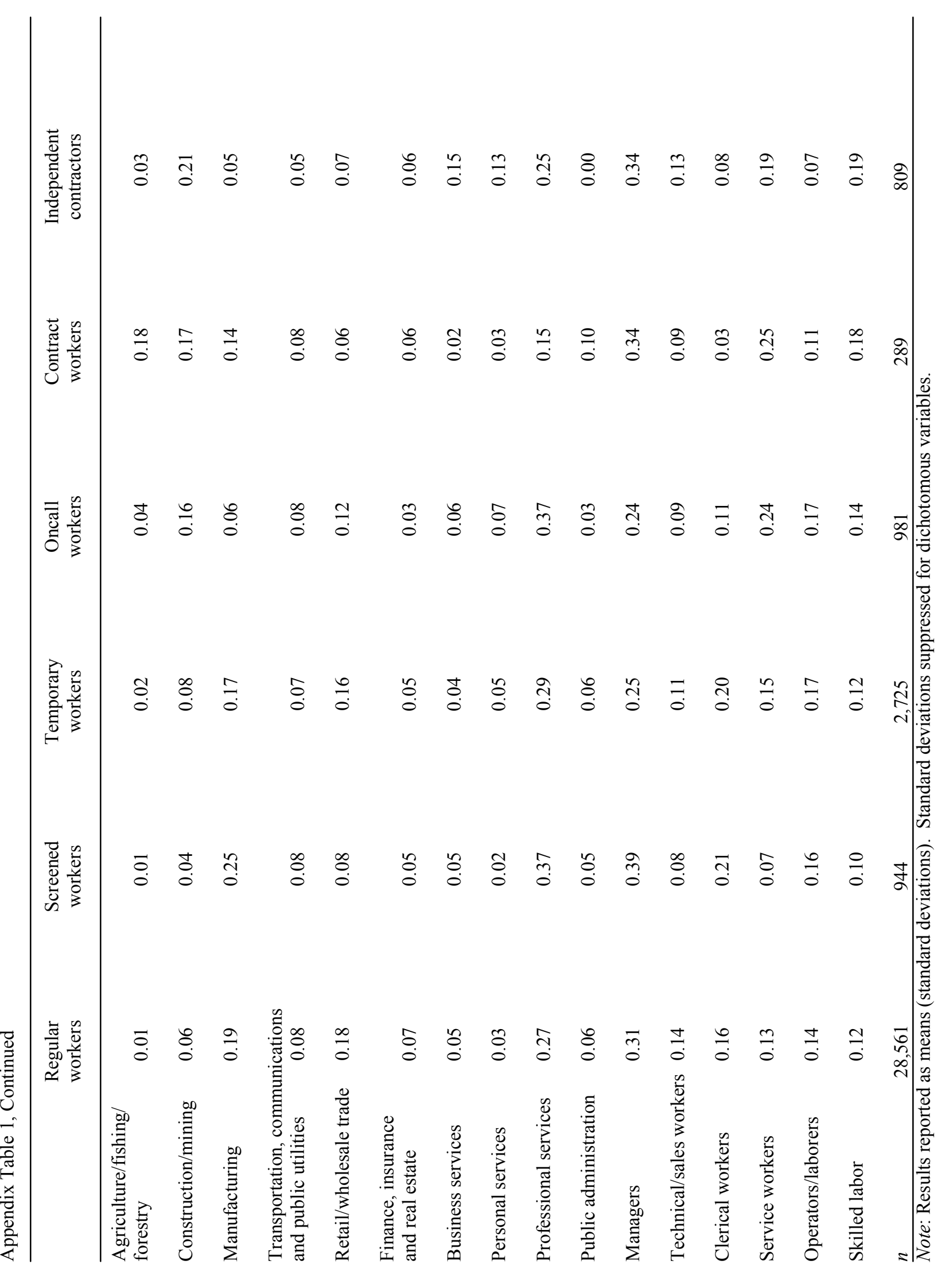




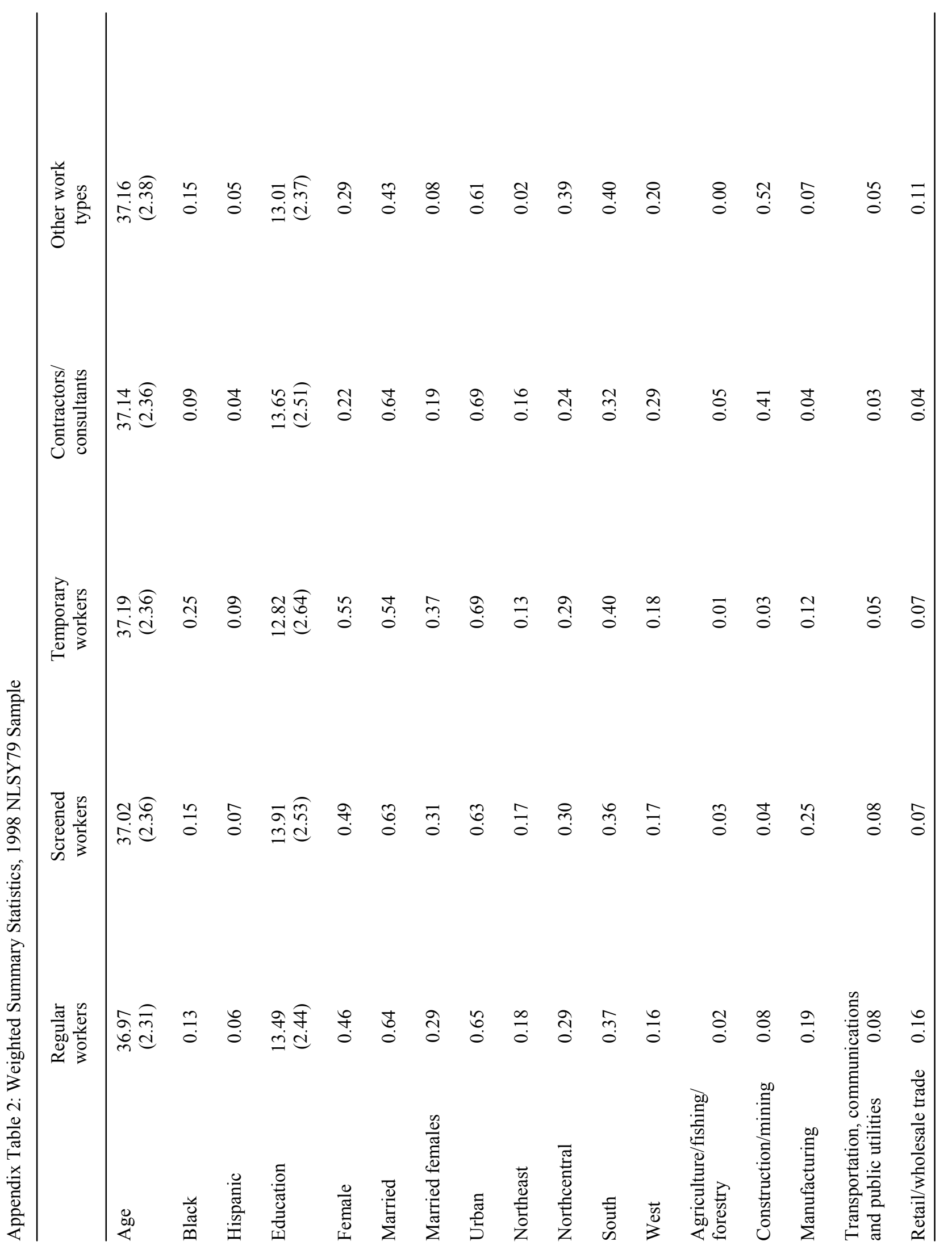

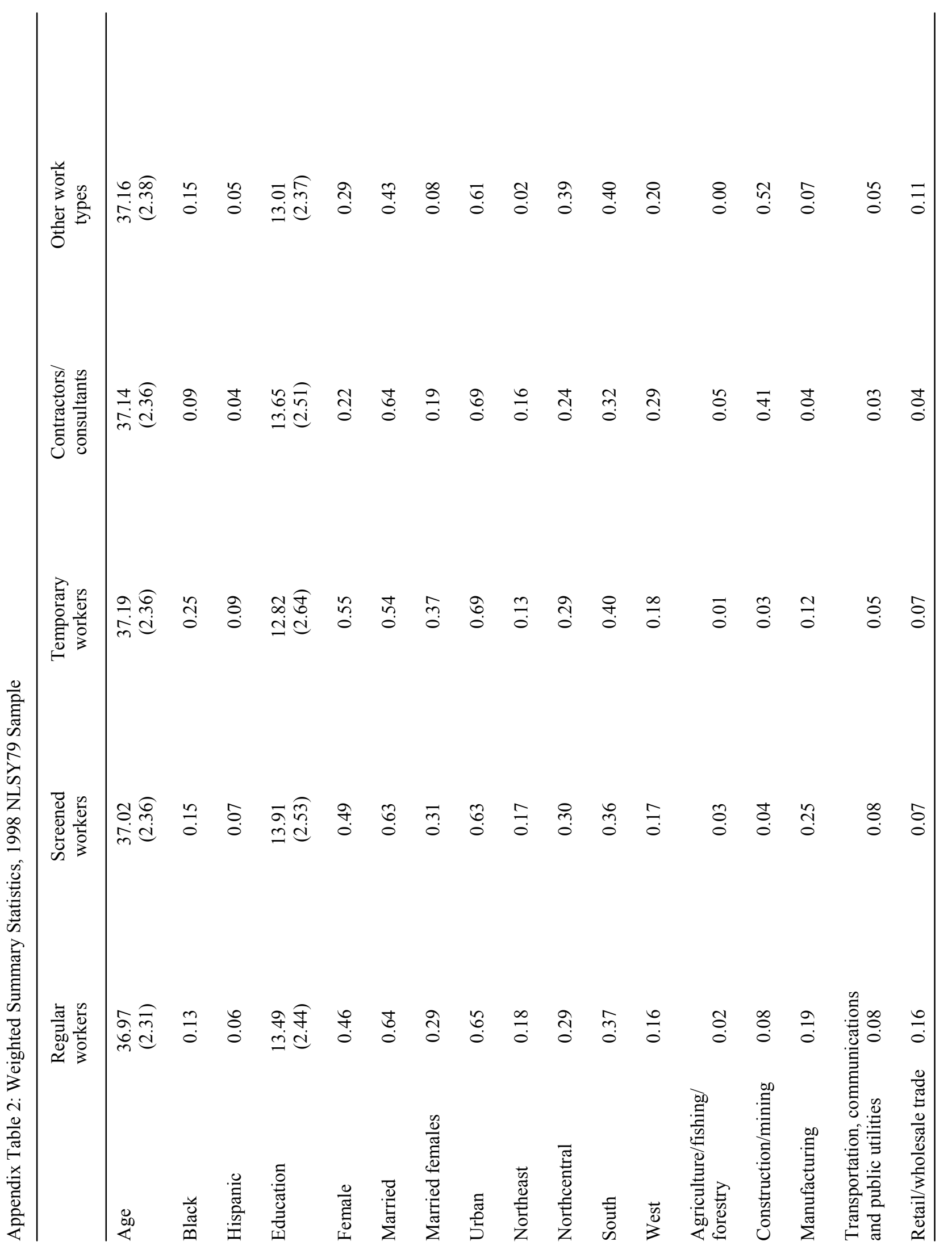

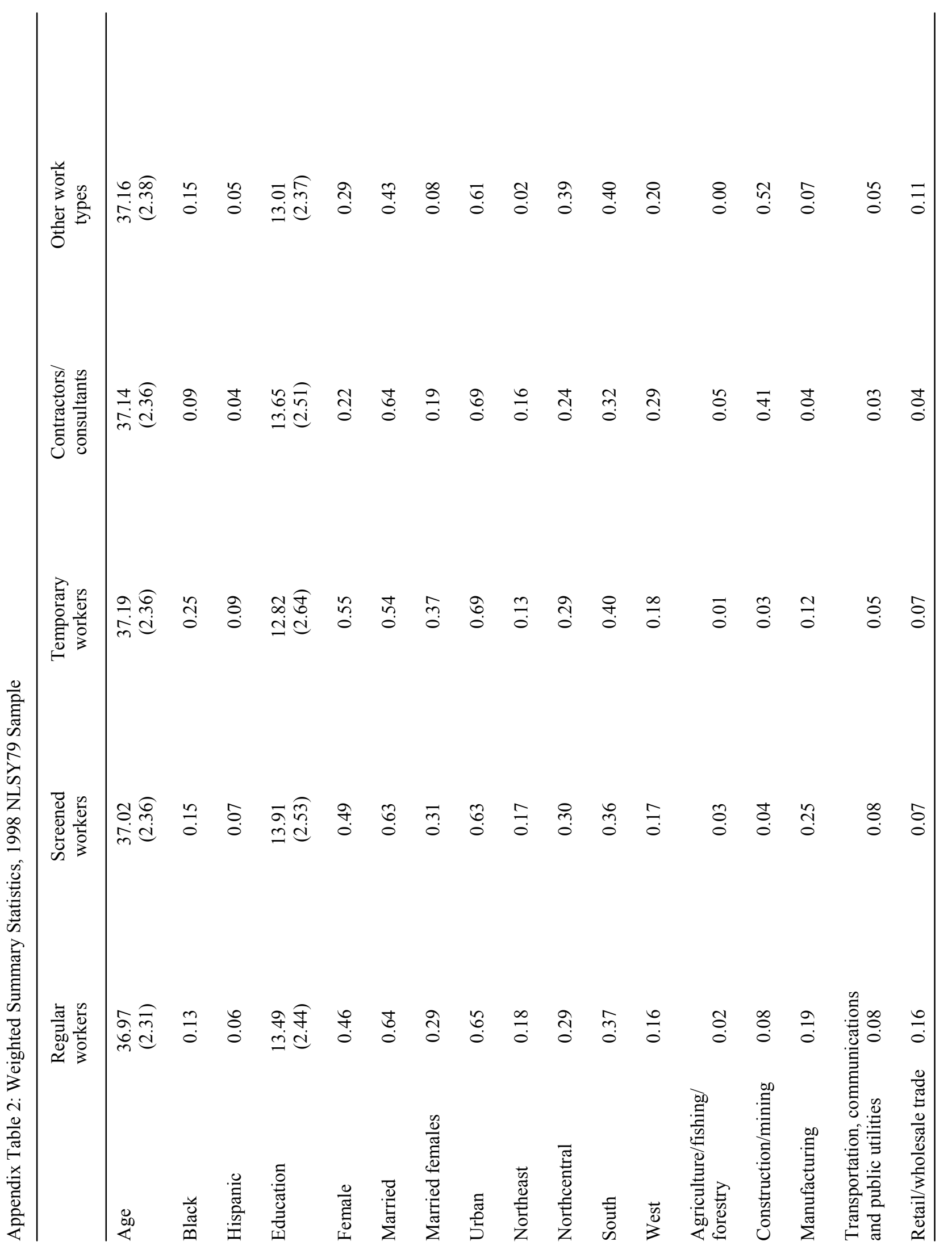




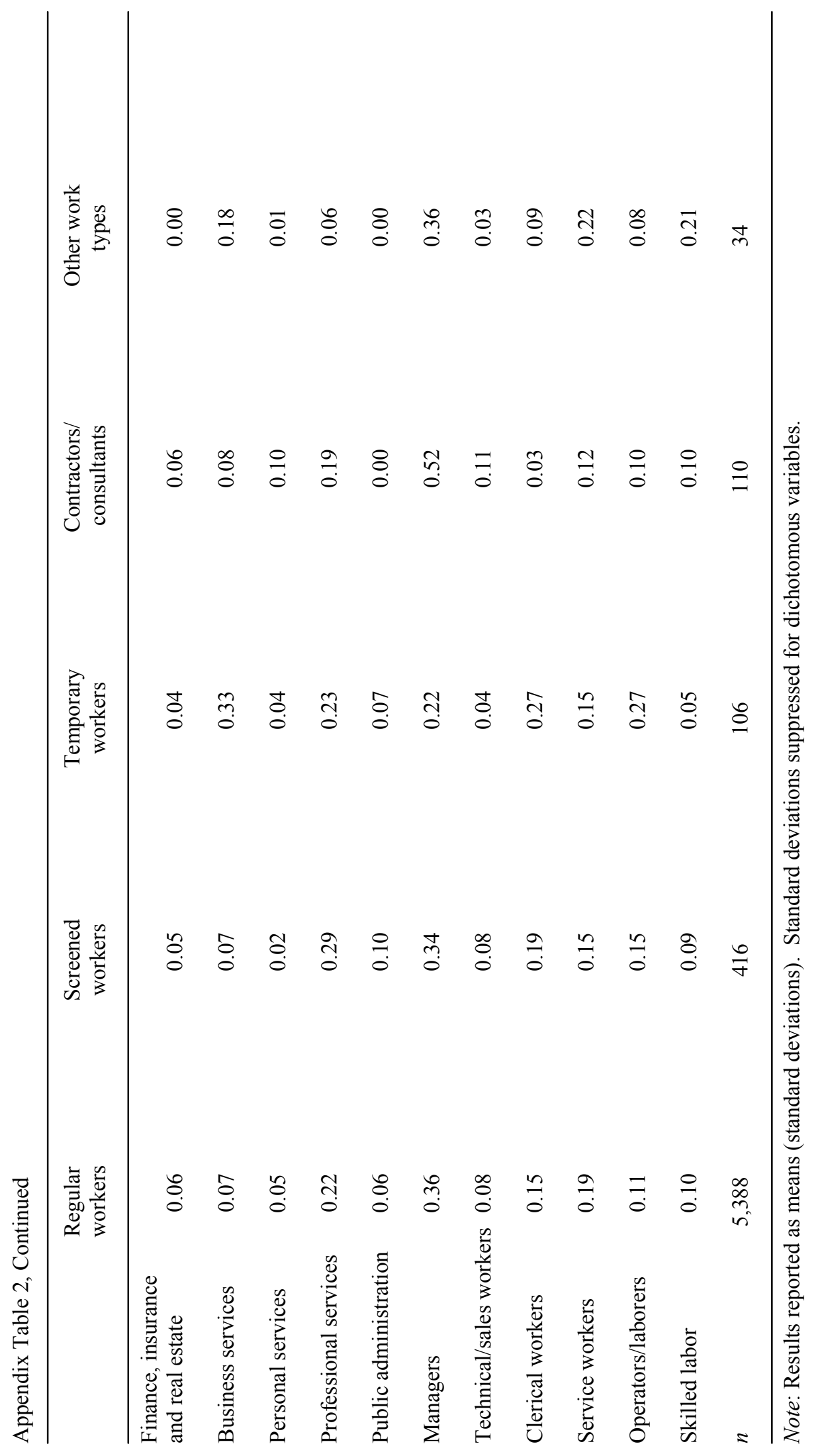


Appendix Table 3: Full OLS Results, CAEAS/CPS Pooled Sample

\begin{tabular}{|c|c|c|c|}
\hline $\begin{array}{l}\text { Screened } \\
\text { workers }\end{array}$ & $\begin{array}{c}0.020^{*} \\
(0.012)\end{array}$ & $\begin{array}{l}\text { Temporary } \\
\text { workers }\end{array}$ & $\begin{array}{l}-0.105 * * * \\
(0.009)\end{array}$ \\
\hline $\begin{array}{l}\text { Oncall } \\
\text { workers }\end{array}$ & $\begin{array}{l}-0.063 * * * \\
(0.016)\end{array}$ & $\begin{array}{l}\text { Contract } \\
\text { workers }\end{array}$ & $\begin{array}{l}0.100 * * * \\
(0.028)\end{array}$ \\
\hline $\begin{array}{l}\text { Independent } \\
\text { contractors }\end{array}$ & $\begin{array}{c}0.188 \\
(0.023)\end{array}$ & Age & $\begin{array}{l}0.042 * * * \\
(0.002)\end{array}$ \\
\hline $\mathrm{Age}^{2}$ & $\begin{array}{l}-0.000 * * * \\
(0.000)\end{array}$ & Black & $\begin{array}{l}-0.057 * * * \\
(0.008)\end{array}$ \\
\hline Other & $\begin{array}{l}-0.027 * * \\
(0.011)\end{array}$ & High school diploma & $\begin{array}{l}0.189 * * * \\
(0.009)\end{array}$ \\
\hline Some college & $\begin{array}{l}0.252 * * * \\
(0.010)\end{array}$ & Associates degree & $\begin{array}{l}0.304 * * * \\
(0.011)\end{array}$ \\
\hline Bachelors degree & $\begin{array}{l}0.447 * * * \\
(0.011)\end{array}$ & Masters degree & $\begin{array}{l}0.542 * * * \\
(0.014)\end{array}$ \\
\hline $\mathrm{JD} / \mathrm{MD} / \mathrm{PhD}$ & $\begin{array}{l}0.638 * * * \\
(0.020)\end{array}$ & Female & $\begin{array}{l}-0.138 * * * \\
(0.009)\end{array}$ \\
\hline Married & $\begin{array}{l}0.103 * * * \\
(0.008)\end{array}$ & Married females & $\begin{array}{l}-0.104 * * * \\
(0.010)\end{array}$ \\
\hline Urban & $\begin{array}{l}0.126^{* * *} \\
(0.006)\end{array}$ & Northcentral & $\begin{array}{l}-0.053 * * * \\
(0.007)\end{array}$ \\
\hline South & $\begin{array}{l}-0.089 \\
(0.007)\end{array}$ & West & $\begin{array}{l}-0.028 * * * \\
(0.007)\end{array}$ \\
\hline Construction/mining & $\begin{array}{l}0.160 * * * \\
(0.023)\end{array}$ & $\begin{array}{l}\text { Transportation, communications } \\
\text { and public utilities }\end{array}$ & $\begin{array}{l}0.212 * * * \\
(0.022)\end{array}$ \\
\hline Retail/wholesale trade & $\begin{array}{l}-0.110 * * * \\
(0.021)\end{array}$ & $\begin{array}{l}\text { Finance, insurance, and } \\
\text { real estates }\end{array}$ & $\begin{array}{l}0.125 * * * \\
(0.023)\end{array}$ \\
\hline Business services & $\begin{array}{l}0.073 * * * \\
(0.023)\end{array}$ & Personal services & $\begin{array}{l}-0.066^{* * * *} \\
(0.024)\end{array}$ \\
\hline Professional services & $\begin{array}{l}0.045^{* *} \\
(0.021)\end{array}$ & Public administration & $\begin{array}{l}0.215 * * * \\
(0.022)\end{array}$ \\
\hline Technical/sales workers & $\begin{array}{l}-0.139 * * * \\
(0.009)\end{array}$ & Clerical workers & $\begin{array}{l}-0.285 * * * \\
(0.008)\end{array}$ \\
\hline Service workers & $\begin{array}{l}-0.469 * * * \\
(0.010)\end{array}$ & Operators/laborers & $\begin{array}{l}-0.361 * * * \\
(0.010)\end{array}$ \\
\hline
\end{tabular}


Appendix Table 3, Continued

\begin{tabular}{lccc}
\hline Skilled labor & $-0.149 * * *$ & 1997 & $0.050^{* * *}$ \\
& $(0.010)$ & & $(0.006)$ \\
1999 & $0.113^{* * *}$ & Intercept & $1.309 * * *$ \\
& $(0.006)$ & & $(0.047)$ \\
$n$ & 34,309 & & \\
Adjusted $\mathrm{R}^{2}$ & 0.42 & & \\
\hline
\end{tabular}

Notes: Huber-White standard errors to correct for heteroskedasticity in parentheses.

$* * *, * *, *$ denote significance at the $.01, .05$, and .10 levels, respectively. 
Appendix Table 4: Full OLS Results (1998 NLSY79 data)

\begin{tabular}{|c|c|c|c|}
\hline $\begin{array}{l}\text { Screened } \\
\text { workers }\end{array}$ & $\begin{array}{c}0.019 \\
(0.018)\end{array}$ & $\begin{array}{l}\text { Temporary } \\
\text { workers }\end{array}$ & $\begin{array}{l}-0.118 * * * \\
(0.044)\end{array}$ \\
\hline $\begin{array}{l}\text { Contractors/ } \\
\text { consultants }\end{array}$ & $\begin{array}{c}0.046 \\
(0.058)\end{array}$ & $\begin{array}{l}\text { Other work } \\
\text { types }\end{array}$ & $\begin{array}{c}0.090 \\
(0.058)\end{array}$ \\
\hline Jobs & $\begin{array}{l}-0.018 \\
(0.014)\end{array}$ & Experience & $\begin{array}{c}0.006 \\
(0.007)\end{array}$ \\
\hline Experience $^{2}$ & $\begin{array}{l}0.001^{* *} \\
(0.000)\end{array}$ & Tenure & $\begin{array}{l}0.037 * * * \\
(0.003)\end{array}$ \\
\hline Tenure $^{2}$ & $\begin{array}{l}-0.001 * * * \\
(0.000)\end{array}$ & Age & $\begin{array}{l}-0.028 \\
(0.081)\end{array}$ \\
\hline $\mathrm{Age}^{2}$ & $\begin{array}{c}0.000 \\
(0.001)\end{array}$ & Black & $\begin{array}{l}-0.044 * * * \\
(0.013)\end{array}$ \\
\hline Hispanic & $\begin{array}{l}-0.008 \\
(0.016)\end{array}$ & Education & $\begin{array}{l}0.064 * * * \\
(0.003)\end{array}$ \\
\hline Female & $\begin{array}{l}-0.101 * * * \\
(0.018)\end{array}$ & Married & $\begin{array}{l}0.123 * * * \\
(0.016)\end{array}$ \\
\hline Married females & $\begin{array}{l}-0.129 * * * \\
(0.022)\end{array}$ & Urban & $\begin{array}{c}0.009 \\
(0.012)\end{array}$ \\
\hline Northcentral & $\begin{array}{l}-0.112 * * * \\
(0.018)\end{array}$ & South & $\begin{array}{l}-0.155^{* * * *} \\
(0.017)\end{array}$ \\
\hline West & $\begin{array}{l}-0.020 \\
(0.020)\end{array}$ & $\begin{array}{l}\text { Construction/ } \\
\text { mining }\end{array}$ & $\begin{array}{l}0.349 * * * \\
(0.056)\end{array}$ \\
\hline Manufacturing & $\begin{array}{l}0.296 * * * \\
(0.053)\end{array}$ & $\begin{array}{l}\text { Transportation, communications } \\
\text { and public utilities }\end{array}$ & $\begin{array}{l}0.356 * * * \\
(0.055)\end{array}$ \\
\hline Retail/wholesale trade & $\begin{array}{c}0.019 \\
(0.054)\end{array}$ & $\begin{array}{l}\text { Finance, insurance, and } \\
\text { real estate }\end{array}$ & $\begin{array}{l}0.331 * * * \\
(0.057)\end{array}$ \\
\hline Business services & $\begin{array}{l}0.254 * * * \\
(0.056)\end{array}$ & Personal Services & $\begin{array}{c}0.021 \\
(0.060)\end{array}$ \\
\hline Professional services & $\begin{array}{l}0.118^{* *} \\
(0.053)\end{array}$ & Public Administration & $\begin{array}{l}0.287 * * * \\
(0.055)\end{array}$ \\
\hline Technical/sales workers & $\begin{array}{l}-0.056^{* *} \\
(0.024)\end{array}$ & Clerical workers & $\begin{array}{l}-0.240 * * * \\
(0.017)\end{array}$ \\
\hline Service workers & $\begin{array}{l}-0.272 * * * \\
(0.018)\end{array}$ & Operators/laborers & $\begin{array}{l}-0.323 * * * \\
(0.020)\end{array}$ \\
\hline Skilled labor & $\begin{array}{l}-0.237 * * * \\
(0.022)\end{array}$ & Intercept & $\begin{array}{c}2.064 \\
(1.480)\end{array}$ \\
\hline $\begin{array}{l}n \\
\text { Adjusted R } \\
\end{array}$ & $\begin{array}{c}6,054 \\
0.45 \\
\end{array}$ & & \\
\hline
\end{tabular}

Notes: Huber-White standard errors to correct for heteroskedasticity in parentheses.

$* * *, * *, *$ denote significance at the $.01, .05$, and .10 levels, respectively. 
Appendix Table 5: Full Logit Estimates of Access to Employer-Related Health Insurance (1998 NLSY79 data)

\begin{tabular}{|c|c|c|c|}
\hline $\begin{array}{l}\text { Screened } \\
\text { workers }\end{array}$ & $\begin{array}{l}0.593 * * * \\
(0.185) \\
{[0.065]}\end{array}$ & $\begin{array}{l}\text { Temporary } \\
\text { workers }\end{array}$ & $\begin{array}{l}-1.602 * * * \\
(0.277) \\
{[-0.175]}\end{array}$ \\
\hline $\begin{array}{l}\text { Contractors/ } \\
\text { consultants }\end{array}$ & $\begin{array}{c}-2.345 * * * \\
(0.356) \\
{[-0.257]}\end{array}$ & $\begin{array}{l}\text { Other work } \\
\text { types }\end{array}$ & $\begin{array}{c}-0.263 \\
(0.419) \\
{[-0.029]}\end{array}$ \\
\hline Jobs & $\begin{array}{l}-0.224 * * \\
(0.087) \\
{[-0.025]}\end{array}$ & Experience & $\begin{array}{c}0.040 \\
(0.044) \\
{[0.004]}\end{array}$ \\
\hline Experience $^{2}$ & $\begin{array}{c}0.001 \\
(0.002) \\
{[0.000]}\end{array}$ & Tenure & $\begin{array}{l}0.147 * * * \\
(0.028) \\
{[0.016]}\end{array}$ \\
\hline Tenure $^{2}$ & $\begin{array}{c}-0.004^{* *} \\
(0.002) \\
{[-0.000]}\end{array}$ & Age & $\begin{array}{c}0.902 \\
(0.579) \\
{[0.099]}\end{array}$ \\
\hline $\mathrm{Age}^{2}$ & $\begin{array}{c}-0.013 * \\
(0.008) \\
{[-0.001]}\end{array}$ & Black & $\begin{array}{l}0.282 * * * \\
(0.101) \\
{[0.031]}\end{array}$ \\
\hline Hispanic & $\begin{array}{c}0.052 \\
(0.115) \\
{[0.006]}\end{array}$ & Education & $\begin{array}{l}0.083 * * * \\
(0.020) \\
{[0.009]}\end{array}$ \\
\hline Female & $\begin{array}{c}0.062 \\
(0.122) \\
{[0.007]}\end{array}$ & Married & $\begin{array}{l}0.512 * * * \\
(0.114) \\
{[0.056]}\end{array}$ \\
\hline Married females & $\begin{array}{l}-0.560 * * * \\
(0.157) \\
{[-0.061]}\end{array}$ & Urban & $\begin{array}{c}0.077 \\
(0.089) \\
{[0.009]}\end{array}$ \\
\hline Northcentral & $\begin{array}{c}-0.083 \\
(0.131) \\
{[-0.009]}\end{array}$ & South & $\begin{array}{c}-0.028 \\
(0.121) \\
{[-0.003]}\end{array}$ \\
\hline West & $\begin{array}{c}0.212 \\
(0.142) \\
{[0.023]}\end{array}$ & $\begin{array}{l}\text { Construction/ } \\
\text { mining }\end{array}$ & $\begin{array}{l}0.554 * * \\
(0.255) \\
{[0.061]}\end{array}$ \\
\hline Manufacturing & $\begin{array}{l}2.171 * * * \\
(0.254) \\
{[0.237]}\end{array}$ & $\begin{array}{l}\text { Transportation, communications } \\
\text { and public utilities }\end{array}$ & $\begin{array}{l}1.727 * * * \\
(0.271) \\
{[0.189]}\end{array}$ \\
\hline Retail/wholesale trade & $\begin{array}{l}0.705^{* * *} \\
(0.240) \\
{[0.077]}\end{array}$ & $\begin{array}{l}\text { Finance, insurance, and } \\
\text { real estate }\end{array}$ & $\begin{array}{l}1.324 * * * \\
(0.285) \\
{[0.145]}\end{array}$ \\
\hline Business services & $\begin{array}{l}0.938 * * * \\
(0.255) \\
{[0.103]}\end{array}$ & Personal services & $\begin{array}{c}0.085 \\
(0.270) \\
{[0.009]}\end{array}$ \\
\hline
\end{tabular}


Appendix Table 5, Continued

\begin{tabular}{lccc}
\hline Professional services & $1.414 * * *$ & Public administration & $\begin{array}{c}2.421^{* * *} \\
(0.331)\end{array}$ \\
& $(0.245)$ & & {$[0.265]$} \\
& {$[0.155]$} & & -0.031 \\
Technical/sales workers & 0.008 & Clerical workers & $(0.134)$ \\
& $(0.173)$ & & {$[-0.003]$} \\
Service workers & {$[0.001]$} & Operators/laborers & $-0.603 * * *$ \\
& $-0.589 * * *$ & & $(0.147)$ \\
& $(0.124)$ & & {$[-0.066]$} \\
Skilled labor & {$[-0.064]$} & Intercept & -17.455 \\
& $-0.624 * * *$ & & $(10.637)$ \\
& $(0.168)$ & & \\
Log L & {$[-0.069]$} & & \\
\hline
\end{tabular}

Notes: Results reported as estimated coefficient, standard errors in parentheses, and marginal effects in brackets. $* * *, * *, *$ denote significance at the $.01, .05$, and .10 levels, respectively. 